\title{
31. DSDP SITE 397: CLIMATOLOGICAL, SEDIMENTOLOGICAL, AND OCEANOGRAPHIC CHANGES IN THE NEOGENE AUTOCHTHONOUS SEQUENCE
}

\author{
L. Diester-Haass, Geologisches Institut der Universität Kiel, 2300 Kiel, West Germany ${ }^{1}$
}

\begin{abstract}
The late Quaternary was characterized by high fertility and by numerous changes between arid climate (low terrigenous input, high desert quartz numbers) and humid climate with river supply (high terrigenous input, low desert quartz numbers, input of shallow water material due to lowered sea level). A strong upwelling influence correlates with humid climate except for three samples where it coincides with arid climate. The early Quaternary had more constant conditions (mainly arid, less fertile). Five pulses with increased dissolution of planktonic foraminifers occur. There are several intervals with abundant volcanic material, correlating with volcanic phases on the Canary Islands.

The Pliocene was a period with rather constant conditions. Climate was arid except for one humid period in the late Pliocene. There was a shallow water supply of sediments in small amounts during the whole period. In the upper Pliocene, three layers with abundant coarse-sized shallow water supply occur. Weak upwelling influences can be observed only in the uppermost sediments from the later Pliocene ( 3 m.y.B.P. to Quaternary). In the same interval, there are three pulses with increased $\mathrm{CaCO}_{3}$ dissolution. Otherwise dissolution is rather constant, except in the lower Pliocene, where it increased. Small quantities of volcanic glass are present throughout the Pliocene, probably supplied by submarine downslope transport from the Canary Island continental slope.

The late Miocene resembled the Quaternary with changes between arid and humid climate, the latter correlating with shallow water supply but without upwelling influence. Volcanic material increases in the lowest sediments from the later Miocene; $\mathrm{CaCO}_{3}$ dissolution is strongest in this interval.
\end{abstract}

\section{INTRODUCTION}

Coarse-fraction analyses $(>40 \mu \mathrm{m})$ were conducted on the autochthonous upper Miocene to Recent section (Sub-units 1A, B) of Site 397 (Cores 397-1 through 397-56), situated south of the Canary Islands $\left(26^{\circ} 50.7^{\prime} \mathrm{N}, 15^{\circ} 10.8^{\prime} \mathrm{W}, 2900 \mathrm{~m}\right.$ water depth). Our analyses sought to answer the following questions:

1) What changes of climate occurred in the northern Sahara during the Neogene?

2) How did upwelling influence the sediments?

3) Have there been changes in $\mathrm{CaCO}_{3}$ dissolution?

4) When was the most intense volcanic influene on the sediments? Can it be correlated with main volcanic phases of the Canary Island? (cf., Schmincke et al., this volume).

5) What is the role of shallow water supply in the hemipelagic sediments?

The questions are treated on the background of knowledge deduced from the studies of the Neogene

\footnotetext{
'Present address: Geologisches Inst. der Univ., Pleicherwall 1, 87 Würzburg, West Germany.
}

sequence at Site 369 of Leg 41 (Diester-Haass, 1978a; Diester-Haass and Schrader, in press) and of upper Quaternary sediments from the same area (DiesterHaass, 1975a, b, 1977, 1978b; Diester-Haass et al., 1973). The Pliocene and Quaternary sequence at Site 369 , because of its shortness (about $14 \mathrm{~m}$ ) did not allow conclusions to the above-mentioned questions. Site 397 , with its 140 meters of Quaternary and 268 meters of Pliocene sediments, was our principal focus of study.

Sample intervals were large: generally, one sample per core section (i.e., $150 \mathrm{~cm}$ ). Considering sedimentation rates of 5 to $8 \mathrm{~cm} / 1000$ years (see Site Report, this volume), samples represent 20,000 to 30,000 year intervals. This has to be considered when making conclusions about cycles or climatic variations, and when comparing the data with that from upper Quaternary cores (where samples were taken every $10 \mathrm{~cm}$ ).

\section{METHODS}

The samples of Cores 2 through 28 were dried at $60^{\circ} \mathrm{C}$ and weighed. From Cores 29 through 56, only small sub-samples were weighed and dried, to determine their water content. The remaining sample material was weighed wet and the dry weight calculated. 
The samples were washed through 40 and $63 \mu \mathrm{m}$ sieves. The fractions 40 to 63 and $>63 \mu \mathrm{m}$ were dried and weighed, and their percentages of the total sediment were calculated. The sand fraction $(>63 \mu \mathrm{m})$ was sieved into four sub-fractions: 63 to 125,125 to 250,250 to 500 , and 500 to $1000 \mu \mathrm{m}$. The weight of each fraction was measured and its percentage of the total sand fraction was calculated. With 800 grains counted in each fraction ( 3200 to 4000 grains per sample), the following grain types were identified in the component analysis: benthic foraminifers (calcareous and arenaceous), planktonic foraminifers (whole tests and fragments), sponges, mollusks (bivalves, gastropods, pteropods), ostracodes, echinoderms, serpulidae, fish debris, radiolarians, and diatoms; and quartz grains (colorless and with red iron staining), mica, other minerals (feldspar, dark minerals), dolomite, volcanic ash and glass, glauconite, relict components (black, corroded, bored shells from shallow water environment), phosphorite grains, and pyrite. We calculated the percentage of each grain type in each fraction and in the total sand fraction.

No evident influence of drilling disturbance could be seen from the results of coarse-fraction analysis, except for the uppermost samples in Core 2.

\section{RESULTS}

\section{Grain-Size Distribution}

The amount of the sand fraction in per cent of the total sediment decreases continuously from top to bottom of the investigated sequence, from 3 to 9 per cent in Cores 2 through 10, to less than 0.1 per cent in Core 52 (Figure 1a). The variations in amount of the sand fraction are controlled by several factors.

Amounts of sand can increase when the following occur: (a) increased production of sand-sized organisms, mainly planktonic foraminifers and radiolarians; (b) increased terrigenous supply of sand-sized particles; (c) shallow-water supply leads to an increase in mainly sand-sized shells; (d) decreased dilution of sand fraction by terrigenous fine-fraction supply (variations in terrigenous supply); (e) decreased dissolution of planktonic foraminifers, leading to higher amounts of sand-sized foraminifers; (f) presence of pyrite in the sand fraction (i.e., pyrite is much heavier than the $\mathrm{CaCO}_{3}$ and $\mathrm{SiO}_{2}$ particles); (g) winnowing enriches sand-sized particles.

There are several factors at Site 397 which influence the size of the sand fraction. Production and pyrite amounts seem to play no role in grain-size distribution. It is astonishing that the pyrite in amounts up to 30 per cent of the sand fraction in Cores 52 through 56 does not increase sand fraction percentages. The highest productivity, determined by highest opal and benthic amounts, correlates in general with layers of small amounts of sand. Increase in supply of sand-sized terrigenous material (up to 30 to $50 \%$ ) leads to an increase in sand-fraction percentages in a few cases: Cores 21-6, 22-5, and 23-3. The normal situation is that the quantity of terrigenous components $>63 \mu \mathrm{m}$ is very small (generally, $<5 \%$ ), and inversely related to the curve showing the per cent of sand. This trend is especially evident in Cores 22 through 56, where nearly all increases in the sand fraction correlate with decreases in the amount of terrigenous material $>63 \mu \mathrm{m}$. In the upper part of Hole 397, there is only a limited agreement; in Cores 3 through 5 , there is more terrigenous material $>63 \mu \mathrm{m}$ and less sand fraction than in the interval from Core 6 to Section 9-2, where the opposite is true.

It is presumed that variations in sand-fraction percentages are due to a varying dilution by the terrigenous fine fraction. The terrigenous components $>63$ $\mu \mathrm{m}$, being the coarsest and quantitatively the smallest part of terrigenous input, are sensitve to variations in terrigenous supply. When the coarsest particles increase slightly, the finer fractions increase much more, leading to a strong dilution of mainly biogenous sand components. This is true, however, only for normal hemipelagic sediments, which were not influenced by turbidity currents, etc. This explanation should be checked by carbonate content variations.

In Meteor Core 12309-1, taken proximal to Site 397 (2849 $\mathrm{m}$ water depth), the same explanation for sandfraction per cent variations seemed highly probable for the upper Quaternary sequence. Absolute values of the sand fraction at this Meteor site varied between 3 and 12 per cent.

The supply of shallow water shells, which are mostly sand-sized, does not have a decisive quantitative influence on sand-fraction percentages. On the contrary, shallow water benthic shells increase as terrigenous material increases, i.e., where sand fraction percentages decrease.

An important factor is the fragmentation of planktonic foraminifers. It is presumed that this is an indicator of dissolution, with highest dissolution leading to strongest fragmentation of planktonic foraminifers and, thus, reduction of sand-sized foraminifers. Down to Core 34 , fragmentation varies between 30 and 50 per cent, without influencing the grain-size distribution. In Cores 36 through 44 , a fragmentation increase ( 40 to $60 \%)$ correlates with lower sand fraction percentages ( 1 to $4 \%$ ). In Cores 45 through 50 , the sand fraction forms only 0.5 to 2 per cent; in Core 52 , it is $<0.5$ per cent, which correlates with an increase in fragmentation from 50 to 60 to 50 to 75 per cent. In Core 52, the lowest sand fraction amounts and highest fragmentation values coincide. The increase in sand fraction in Cores 54 and 55 ( 0.5 to $2 \%)$ correlates with reduced fragmentation ( 45 to $65 \%$ ).

The curve showing the amount of sand (Figure 1a) is controlled by three factors: (1) varying dilution by fine-grained terrigenous material; (2) fragmentation and (thus) dissolution changes of planktonic foraminifers; and (3) short pulses of terrigenous supply with large quantitites of sand-sized components.

The influence of bottom currents cannot be deduced from the present data.

Percentages of the 40 to $63 \mu \mathrm{m}$ fraction are smaller and generally parallel to those of the sand fraction (Figure 1a). 


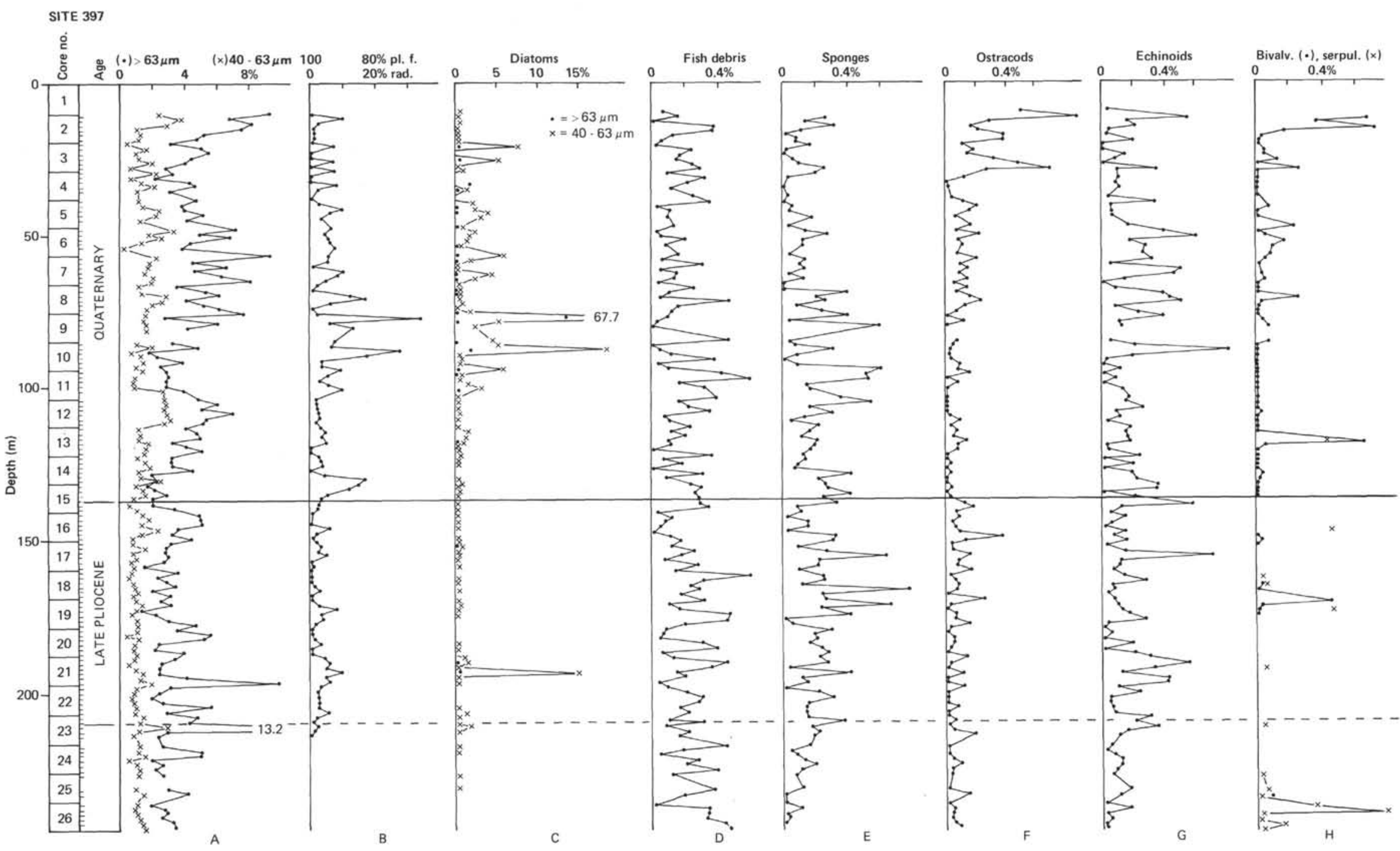

Figure 1. Results of coarse fraction analysis. (a) Per cent sand $>63 \mu \mathrm{m}$ ) and 40 to $63 \mu \mathrm{m}$ fraction of total sediment; (b) radiolarian/planktonic foraminiferal ratio, calculated as $(r / r+p l . f) \times 100 ;.(c)$ per cent diatoms in the 40 to 63 and $>63 \mu \mathrm{m}$ fractions; (d) per cent fish debris in the sand fraction; (e) per cent sponges in the sand fraction; $(f)$ per cent ostracodes in the sand fraction; $(g)$ per cent echinoids in the sand fraction; $(h)$ per cent bivalves and serpulides in the sand fraction; (i) benthic/planktonic ratio of foraminifers, calculated as $(b / b+p l) \times 100 ;.(j)$ per cent terrigenous material in the 40 to 63 and $>63 \mu \mathrm{m}$ fractions; $(k)$ desert; quartz numbers, calculated as (red-stained quartz/colorless quartz) X 100; (l) per cent glauconite in the 40 to 63 and $>63 \mu \mathrm{m}$ fractions; $(\mathrm{m})$ per cent relict material in the 40 to 63 and $>63 \mu \mathrm{m}$ fractions; ( $n$ ) per cent volcanic material in the 40 to 63 and $>63 \mu \mathrm{m}$ fractions; $(0)$ per cent pyrite in the $>63 \mu \mathrm{m}$ fraction; 

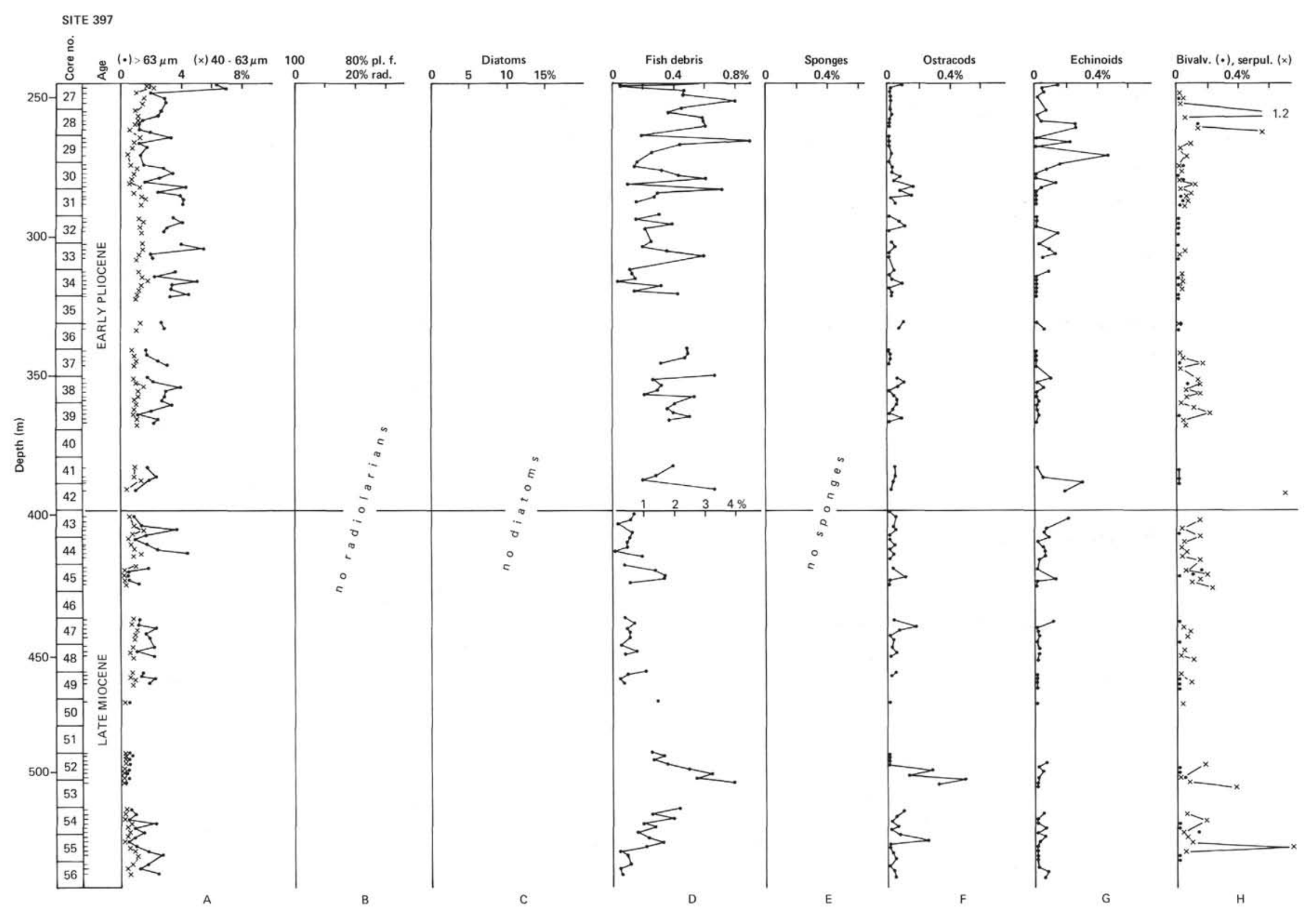

Figure 1. (Continued). 


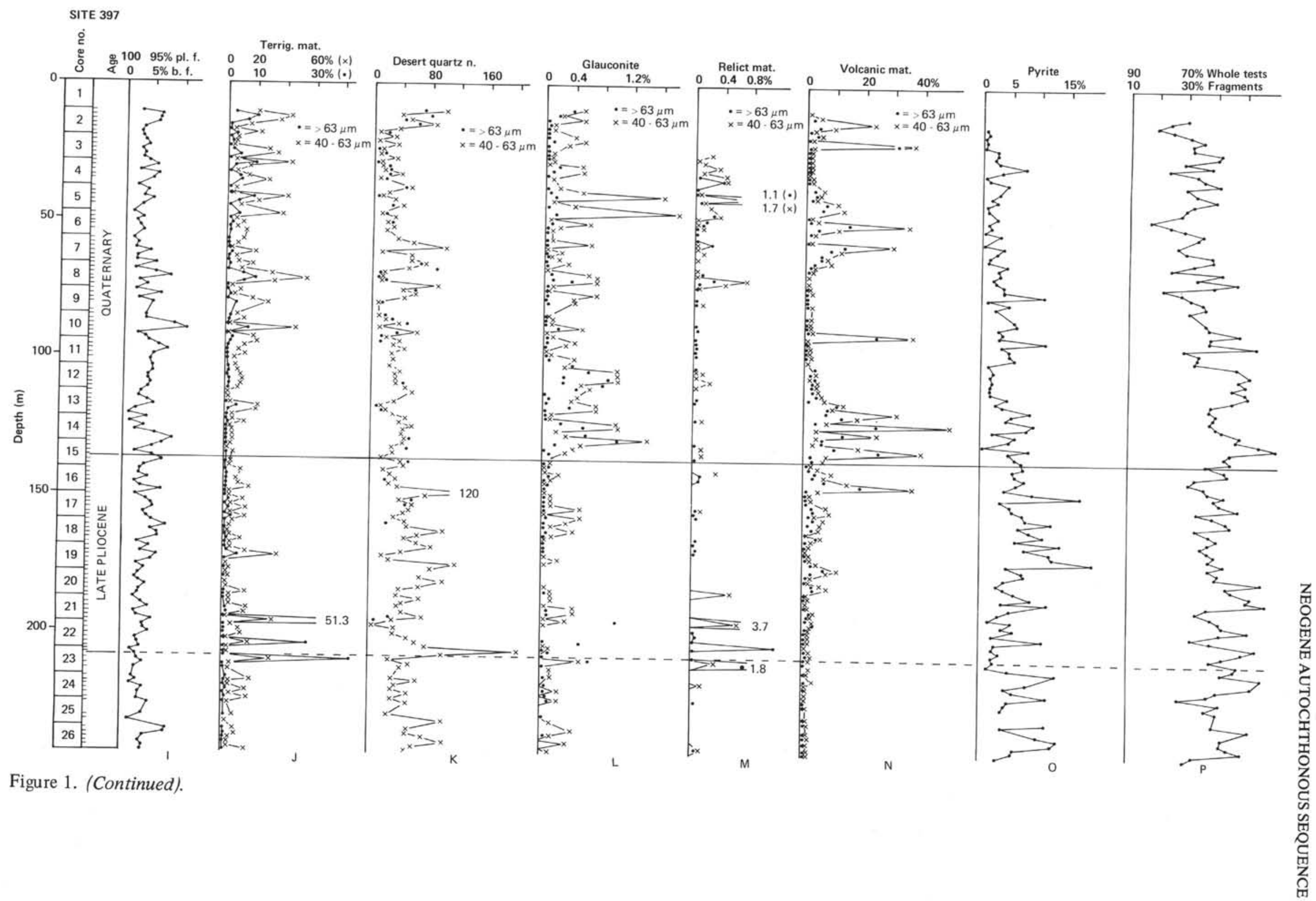




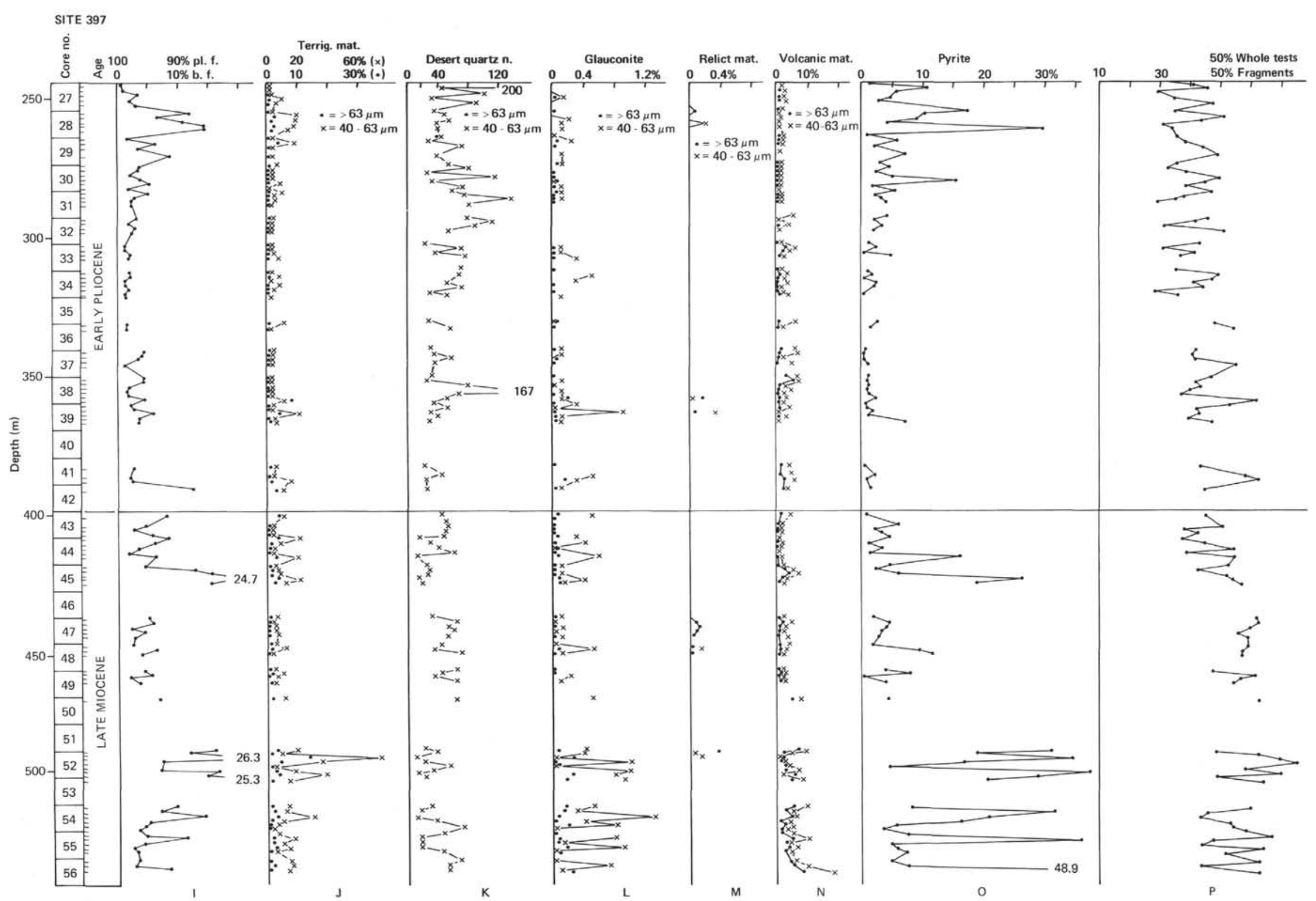

Figure 1. (Continued). 


\section{Composition of the Sand Fraction}

The composition of the sand fraction is summarized on Table 1. Amounts of radiolarians and benthic foraminifers are not plotted as percentages, but as ratios to planktonic foraminifers. The production of the latter is rather constant in this area, except for upwelling influence areas, at least during the late Quaternary (Diester-Haass, 1976b). Therefore, using ratios can avoid misinterpretation due to dilution of radiolarians and benthics by terrigenous and volcanic material.

Percentages of planktonic foraminifers, the most important constituent of the sand fraction, are controlled by dilution of non-biogenous particles.

Radiolarians: The percentage of radiolarians from the sum of radiolarians plus planktonic foraminifers can be seen on Figure 1(b). Radiolarians are only present in Cores 2 through 24. Maximum values (10 to $30 \%$ ) occur in the Quaternary section (Cores 2 through 15). In the upper Pliocene (Cores 16 through 24), there is $<5$ per cent (except for a few samples where 5 to $10 \%$ are observed).

There is a strikingly good correlation between amounts of radiolarians and terrigenous components in the sand fraction. Nearly each peak in terrigenous material correlates with an increase in radiolarians (e.g., Sections 2-2, 3-2, 3-5, 4-1, 4-4, 5-3, 6-1, 6-5, 7-4, 8-4, 9-4, 10-4, and 11-1). Even small variations in the lower part of the radiolarian sequence correlate in general with terrigenous material. The three layers with highest radiolarian amounts (Sections 9-2, 10-3, and 14-16 to 15-2), however, correspond to layers with a small terrigenous input. Radiolarian amounts are not significantly correlated to amounts of volcanic matter, contrary to results from Site 369 (Diester-Haass, 1978a).

Radiolarian percentages of the same order of magnitude have been found in upper Glacial sediments from the same area (Meteor Core 12309-1), i.e., up to 7 per cent in glacial and $<3$ per cent in interglacial sediments (Diester-Haass, 1977).

Diatoms: Diatoms are rare in the sand fraction (Figure 1c), i.e, $<1$ per cent, except for a few peaks. In the 40 to $63 \mu \mathrm{m}$ fraction, however, diatoms constitute 0 to 8 per cent in Cores 2 through 11 and $<2$ per cent in Cores 12 through 21 (except for $15 \%$ in Section 21-4), where radiolarians also decrease. In Core 24, both groups comprise $<0.2$ per cent; they disappear completely in Core 25.

The two radiolarian peaks in Sections 9-2 and 10-3 are also diatom peaks (67.7 and $16 \%$ of the 40 to 63 $\mu \mathrm{m}$ fraction, respectively). The other radiolarian peaks are not always diatom peaks; especially the radiolarian-rich interval spanning Sections 14-6 through 15-2, which does not contain increased diatom amounts.

Fish debris: The amount of fish debris in per cent of the sand fraction (Figure 1d) varies without trend between 0 and 0.6 per cent in Cores 2 through 26. In Cores 27 through 39 , values increase slightly $(0.1$ to $0.8 \%$ ). Fish debris comprises 0.2 to 1.8 per cent in Cores 41 through 51 , is highest in Core 52 (up to $4 \%$ ), and decreases from 2 to 0.3 per cent in Cores 54 through 56. The highest fish debris values in Core 52 coincide with strongest dissolution of $\mathrm{CaCO}_{3}$, as revealed by fragmentation of planktonic foraminifers. The radiolarian and diatom maxima are not accompanied by an increase in fish debris.

Benthics: Benthics consist mainly of foraminifers with rare occurrences of other organisms such as sponges, ostracodes, echinoderms, pelecypods, and serpulidae. Amounts of total benthics can be seen in Table 1. Percentages of benthics other than foraminifers are plotted although they are so rare that often only a few shells or debris are found, thus producing possible statistical errors. Nevertheless, some trends in composition are obvious.

Sponges: In Figure 1e, sponge spicules are plotted as per cent of the sand fraction; they occur in Cores 2 through 26 with their disappearance being stratigraphically below that of radiolarians and diatoms (Core 25). They form 0 to 0.6 per cent of the sand fraction. Maxima and minima correlate only at times with those of radiolarians or diatoms. They never correlate with those of volcanic material.

Ostracodes: Ostracodes (Figure 1f) form 0.1 to 0.8 per cent in Core 2 through Section 4-2, then decrease to $<0.2$ per cent of the sand fraction (with a few layers having higher values). Some of the ostracode maxima correlate with radiolarian maxima (e.g., Sections 2-2, 4-1, 5-3, and 11-2), but each radiolarian peak is not accompanied by an increase in ostracodes.

Echinoderms: Echinoderms show the same general trend as ostracodes: highest values of 0 to 0.7 per cent of the sand fraction in the upper part, from Cores 2 through 23 (Figure $1 \mathrm{~g}$ ). In the lower part, echinoderms (ostracodes) are often absent. Many of the peaks in echinoderm amounts in Cores 2 through 21 coincide with peak abundances of radiolarians (e.g., Sections 2-2, 4-1, 7-4 through 7-5, 8-3 through 8-5, 9-2, 10-3, $11-1,11-5,14-6$ through 15-2, 17-4, 20-4, 21-2, and 21-6). There are, however, some maxima in echinoderms which do not correspond to a radiolarian peak.

Pelecypods: Pelecypods (Figure 1h) are present only in a few specimens. These are not entire shells but debris of bigger, thick, sculptured shells, sometimes with a well-preserved aragonitic layer. Pelecypods are only found in layers rich in terrigenous material, but not every maximum in terrigenous material is accompanied by the presence of pelecypods. They occur mainly in the Quaternary section.

Serpulidae: Serpulidae (Figure 1h) are found as calcareous tubes either without sculpture (more frequently) or with rips. They are absent in the Quaternary section and form up to 1.2 per cent of the sand fraction in some Miocene and Pliocene samples, exactly in those layers where benthic/planktonic ratios of foraminifers increase. The presence of serpulidae is often linked to that of pelecypods.

The benthic/planktonic ratio of foraminifers: This ratio is plotted in Figure $1 \mathrm{i}$ as (benthic foraminifers/ benthic + planktonic foraminifers) $\times 100$. Values are rather constant ( 2 to $8 \%$ ) in Cores 2 to 26 . In Cores 26 
TABLE 1

Composition (\%) of the Sand Fraction ( $>63 \mu \mathrm{m}$ ) at Hole 397, Leg 47A

\begin{tabular}{|c|c|c|c|c|c|c|c|c|c|c|c|}
\hline $\begin{array}{l}\text { Sample No. } \\
\text { (Interval in } \mathrm{cm} \text { ) }\end{array}$ & Radiol. & Diat. & Pl. For. & Fish d. & Benthics & Relict m. & Phosph. & Glauc. & Volc. m. & Pyrite & Terrig. m. \\
\hline $2-1,70$ & 0.07 & - & 93.17 & 0.07 & 3.54 & - & - & 0.37 & 0.44 & - & 2.26 \\
\hline $2-2,60$ & 8.13 & - & 72.61 & 0.16 & 6.65 & - & - & 0.16 & 2.29 & - & 9.65 \\
\hline $2-3,60$ & 1.54 & - & 59.17 & - & 4.30 & - & - & - & 27.81 & - & 7.04 \\
\hline $2-4,60$ & 1.10 & - & 86.27 & 0.38 & 6.38 & - & - & 0.03 & 4.14 & 0.45 & 1.03 \\
\hline $2-5,60$ & 1.21 & - & 93.10 & 0.37 & 3.25 & - & - & - & 1.21 & 0.65 & 0.15 \\
\hline $2-6,30$ & 1.40 & - & 89.05 & 0.13 & 2.70 & - & - & - & 3.51 & 0.19 & 2.93 \\
\hline $3-1,30$ & 0.74 & - & 94.62 & 0.06 & 3.30 & - & - & - & 0.31 & 0.24 & 0.58 \\
\hline $3-2,80$ & 4.84 & 0.41 & 60.02 & 0.03 & 2.26 & - & - & 0.09 & 30.75 & 0.14 & 1.47 \\
\hline $3-3,80$ & 0.19 & - & 92.82 & 0.24 & 3.94 & - & - & - & 0.57 & 2.19 & - \\
\hline $3-4,80$ & 0.07 & - & 92.56 & 0.17 & 2.84 & - & - & - & 0.26 & 2.20 & 1.85 \\
\hline $3-5,60$ & 6.88 & 0.48 & 83.30 & 0.15 & 3.18 & - & - & - & 0.63 & 1.77 & 3.95 \\
\hline $3-6,80$ & 0.80 & 0.03 & 93.39 & 0.25 & 3.22 & - & - & - & - & 2.48 & 0.42 \\
\hline $4-1,80$ & 6.00 & - & 92.42 & 0.29 & 4.61 & - & - & 0.09 & 0.28 & 7.11 & 9.06 \\
\hline $4-2,80$ & 0.43 & - & 88.76 & 0.10 & 5.55 & - & - & 0.16 & 0.08 & 3.14 & 1.70 \\
\hline $4-3,32$ & 0.17 & - & 94.92 & 0.32 & 2.74 & - & - & 0.08 & 0.22 & 0.63 & 0.88 \\
\hline $4-4,35$ & 7.29 & 1.73 & 79.36 & 0.22 & 4.80 & 0.04 & 0.04 & - & 1.27 & 0.99 & 4.23 \\
\hline $4-5,40$ & 2.16 & 0.08 & 84.10 & 0.12 & 4.27 & 0.43 & 0.16 & - & 0.47 & 3.63 & 4.55 \\
\hline $5-1,79$ & 0.33 & - & 91.34 & 0.26 & 2.08 & - & - & - & 2.77 & 2.68 & 0.35 \\
\hline $5-2,80$ & 2.36 & - & 88.17 & 0.36 & 3.75 & - & - & 0.04 & 3.72 & 1.45 & 0.14 \\
\hline $5-3,82$ & 8.15 & 0.06 & 74.44 & 0.07 & 2.90 & 1.10 & 0.03 & 0.13 & 1.97 & 2.19 & 8.66 \\
\hline $5-4,82$ & 5.11 & 0.04 & 79.17 & 0.11 & 4.02 & 0.08 & - & 0.14 & 6.84 & 0.74 & 3.78 \\
\hline $5-5,50$ & 3.30 & - & 86.79 & 0.09 & 2.92 & - & - & 0.03 & 5.17 & 0.82 & 0.88 \\
\hline $6-1,80$ & 6.29 & 0.04 & 83.25 & 0.14 & 3.00 & 0.25 & 0.17 & 0.13 & 0.13 & 2.28 & 4.26 \\
\hline $6-2,80$ & 4.42 & - & 88.54 & 0.03 & 3.26 & 0.13 & - & - & 1.45 & 0.85 & 1.25 \\
\hline $6-3,80$ & 4.67 & - & 74.77 & 0.05 & 2.67 & 0.09 & 0.04 & 0.08 & 14.67 & 1.28 & 1.62 \\
\hline $6-4,80$ & 5.79 & - & 85.63 & 0.21 & 2.78 & - & - & - & 4.13 & 0.37 & 1.01 \\
\hline $6-5,79$ & 6.93 & 0.04 & 82.53 & 0.08 & 3.17 & - & - & - & 1.76 & 3.04 & 1.21 \\
\hline $7-1,80$ & 5.51 & 0.15 & 91.44 & 0.16 & 1.82 & - & - & - & 0.19 & 0.28 & 0.48 \\
\hline $7-2,80$ & 4.48 & 0.04 & 75.59 & 0.07 & 2.47 & 0.22 & - & - & 13.08 & 3.46 & 0.54 \\
\hline $7-3,81$ & 0.79 & - & 86.35 & 0.31 & 1.89 & - & - & 0.03 & 8.18 & 2.23 & 0.17 \\
\hline $7-4,80$ & 9.07 & - & 78.06 & 0.06 & 4.37 & - & - & - & 5.07 & 1.21 & 2.08 \\
\hline $7-5,80$ & 7.66 & - & 82.73 & 0.15 & 2.54 & - & - & 0.04 & 5.04 & 0.92 & 0.76 \\
\hline $7-6,79$ & 4.64 & - & 85.91 & 0.14 & 2.20 & - & - & - & 2.45 & 3.95 & 0.63 \\
\hline $8-1,80$ & 2.87 & - & 86.53 & 0.04 & 5.01 & - & - & 0.05 & 1.31 & 2.61 & 1.44 \\
\hline $8-2,79$ & 0.95 & 0.03 & 92.39 & 0.25 & 1.92 & - & - & - & 0.70 & 2.93 & 0.78 \\
\hline $8-3,80$ & 11.03 & 0.04 & 75.10 & 0.11 & 5.05 & 0.08 & 0.08 & 0.08 & 0.28 & 2.02 & 6.14 \\
\hline $8-4,80$ & 14.02 & - & 66.11 & 0.05 & 6.73 & 0.25 & 0.15 & 0.10 & 0.13 & 2.20 & 10.04 \\
\hline $8-5,79$ & 5.66 & - & 80.02 & 0.47 & 3.31 & 0.05 & 0.09 & 0.36 & 0.25 & 3.54 & 6.40 \\
\hline $8-6,80$ & 1.38 & - & 90.34 & 0.16 & 3.69 & 0.04 & - & 0.04 & 0.27 & 3.46 & 0.59 \\
\hline $9-1$ & 2.19 & 0.09 & 83.89 & 0.12 & 2.37 & - & - & 0.03 & 0.40 & 10.34 & 0.51 \\
\hline $9-2,80$ & 27.11 & 13.63 & 52.06 & 0.10 & 4.31 & - & - & 0.04 & 0.08 & 0.93 & 1.45 \\
\hline $9-3,80$ & 5.77 & 0.12 & 85.66 & 0.03 & 2.67 & - & 0.04 & - & 0.66 & 4.53 & 0.50 \\
\hline $9-4,80$ & 12.42 & - & 76.27 & - & 4.74 & 0.04 & 0.12 & 0.04 & 0.63 & 2.30 & 3.41 \\
\hline $10-1,80$ & 7.03 & 0.03 & 81.14 & 0.47 & 3.38 & - & - & - & 0.78 & 5.43 & 1.54 \\
\hline $10-2,80$ & 6.03 & 0.03 & 82.87 & - & 3.49 & - & - & - & 0.51 & 5.62 & 1.43 \\
\hline $10-3,80$ & 24.23 & 1.88 & 62.65 & 0.05 & 7.01 & - & - & - & 0.62 & 3.15 & 0.28 \\
\hline $10-4,78$ & 14.11 & - & 64.74 & 0.12 & 8.15 & 0.05 & - & 0.19 & 1.37 & 3.64 & 7.60 \\
\hline $10-5,80$ & 2.85 & - & 67.44 & 0.38 & 1.85 & - & - & - & 23.92 & 3.06 & 0.52 \\
\hline $10-6,80$ & 3.50 & - & 80.16 & 0.04 & 3.53 & - & - & 0.04 & 0.15 & 10.44 & 2.15 \\
\hline $11-1,80$ & 8.78 & 0.26 & 81.26 & 0.10 & 4.42 & 0.03 & 0.03 & 0.03 & 0.10 & 3.35 & 1.62 \\
\hline $11-2,80$ & 4.96 & 0.07 & 82.45 & 0.43 & 6.27 & 0.04 & - & - & 0.03 & 4.64 & 0.93 \\
\hline $11-3,80$ & 2.92 & - & 83.35 & 0.59 & 7.36 & - & - & 0.03 & 0.38 & 4.58 & 0.79 \\
\hline $11-4,84$ & 5.16 & - & 83.26 & 0.17 & 4.74 & 0.03 & - & 0.03 & 0.44 & 5.39 & 0.64 \\
\hline $11-5,77$ & 9.55 & 0.20 & 83.75 & 0.32 & 4.43 & - & - & 0.06 & 0.08 & 0.91 & 0.69 \\
\hline $12-1,80$ & 1.89 & 0.20 & 85.89 & 0.39 & 5.42 & 0.03 & - & 0.38 & 2.81 & 1.85 & 1.13 \\
\hline $12-2,80$ & 2.02 & - & 86.13 & 0.16 & 5.53 & - & - & 0.61 & 2.62 & 1.57 & 1.21 \\
\hline $12-3,45$ & 2.50 & - & 87.13 & 0.23 & 4.36 & - & - & 0.27 & 2.90 & 1.72 & 0.81 \\
\hline $12-4,80$ & 2.46 & - & 86.53 & 0.35 & 4.24 & - & 0.07 & 0.86 & 2.59 & 1.37 & 1.52 \\
\hline $12-5,80$ & 2.79 & 0.05 & 86.49 & 0.08 & 4.51 & - & 0.05 & 0.80 & 2.80 & 1.25 & 1.12 \\
\hline $12-6,80$ & 2.17 & - & 87.46 & 0.11 & 4.03 & - & 0.05 & 0.44 & 2.95 & 1.53 & 1.04 \\
\hline $13-1,80$ & 3.06 & - & 85.61 & 0.23 & 3.19 & - & - & - & 3.65 & 4.14 & - \\
\hline $13-2,80$ & 4.47 & 0.03 & 88.38 & 0.12 & 2.82 & 0.04 & - & 0.06 & 1.51 & 2.44 & - \\
\hline $13-3,80$ & 3.36 & - & 77.92 & 0.20 & 3.91 & - & - & 0.03 & 11.21 & 3.30 & - \\
\hline $13-4,80$ & 4.03 & 0.18 & 70.02 & 0.10 & 4.96 & - & - & 0.37 & 7.86 & 8.05 & 4.28 \\
\hline $13-5,75$ & 0.98 & 0.03 & 82.98 & 0.11 & 2.30 & - & - & 0.03 & 7.20 & 5.15 & 1.20 \\
\hline $13-6,80$ & 0.12 & 0.03 & 81.33 & - & 1.28 & - & - & 0.03 & 12.67 & 3.91 & 0.61 \\
\hline $14-1,80$ & 2.48 & - & 79.97 & 0.36 & 3.82 & 0.03 & - & 0.03 & 3.80 & 9.00 & 0.45 \\
\hline $14-2,80$ & 2.32 & - & 62.41 & 0.07 & 1.81 & - & - & 0.23 & 24.15 & 7.67 & 1.25 \\
\hline
\end{tabular}


TABLE 1 - Continued

\begin{tabular}{|c|c|c|c|c|c|c|c|c|c|c|c|}
\hline $\begin{array}{l}\text { Sample No. } \\
\text { (Interval in } \mathrm{cm} \text { ) }\end{array}$ & Radiol. & Diat. & Pl. For. & Fish d. & Benthics & Relict m. & Phosph. & Glauc. & Volc. m. & Pyrite & Terrig. m. \\
\hline $14-3,80$ & 3.93 & 0.04 & 84.64 & 0.18 & 3.85 & - & - & 0.54 & 4.97 & 1.93 & 0.32 \\
\hline $14-4,85$ & 0.28 & - & 80.37 & - & 2.08 & - & - & 0.19 & 13.11 & 5.74 & 0.30 \\
\hline $14-5,80$ & 3.99 & - & 78.74 & 0.30 & 5.43 & - & - & 0.57 & 5.85 & 4.80 & 0.32 \\
\hline $14-6,39$ & 14.72 & 0.07 & 70.40 & 0.09 & 6.99 & - & 0.02 & 1.04 & 6.00 & 0.40 & 0.20 \\
\hline $15-1,80$ & 11.43 & - & 64.77 & 0.23 & 5.19 & - & - & 0.15 & 9.95 & 7.99 & 0.26 \\
\hline $15-2,80$ & 8.22 & 0.05 & 57.47 & 0.29 & 4.34 & - & - & - & 24.86 & 4.56 & 0.20 \\
\hline $15-3,80$ & 5.17 & - & 83.36 & 0.26 & 2.46 & - & - & 0.08 & 2.30 & 5.59 & 0.79 \\
\hline $15-4,80$ & 2.95 & - & 81.90 & 0.28 & 5.02 & - & - & - & 2.68 & 6.94 & 0.16 \\
\hline $15-5,80$ & 2.58 & - & 81.62 & 0.29 & 7.14 & - & - & - & 1.14 & 7.12 & 0.12 \\
\hline $15-6,80$ & 2.54 & - & 85.58 & 0.33 & 3.84 & - & - & 0.08 & 1.74 & 5.20 & 0.25 \\
\hline $16-1,80$ & 0.83 & 0.03 & 85.93 & 0.03 & 3.14 & - & - & - & 3.70 & 5.67 & 0.66 \\
\hline $16-2,95$ & 0.41 & - & 84.46 & 0.12 & 3.00 & 0.09 & - & 0.09 & 3.57 & 7.23 & 1.03 \\
\hline $16-3,90$ & 0.98 & - & 81.41 & 0.08 & 4.12 & 0.08 & - & - & 6.56 & 5.91 & 0.88 \\
\hline $16-4,80$ & 4.72 & - & 69.01 & 0.05 & 1.90 & - & - & 0.05 & 19.44 & 3.91 & 0.80 \\
\hline $16-5,80$ & 1.91 & - & 84.99 & 0.02 & 3.39 & - & 0.03 & - & 0.64 & 8.53 & 0.54 \\
\hline $16-6,91$ & 1.06 & - & 75.17 & 0.11 & 6.24 & - & - & - & 0.37 & 16.74 & 0.09 \\
\hline $17-1,80$ & 2.33 & - & 89.93 & 0.17 & 2.91 & - & - & - & 0.85 & 3.41 & 0.36 \\
\hline $17-2,80$ & 3.35 & 0.04 & 84.49 & 0.12 & 3.95 & - & - & - & 1.31 & 4.89 & 1.73 \\
\hline $17-3,75$ & 2.69 & 0.04 & 83.06 & 0.25 & 5.24 & - & - & - & 2.89 & 5.22 & 0.42 \\
\hline $17-4,80$ & 4.43 & 0.04 & 77.67 & 0.18 & 5.81 & 0.04 & - & - & 2.99 & 7.01 & 1.74 \\
\hline $17-5,83$ & 0.83 & - & 85.49 & 0.08 & 3.90 & - & - & - & 1.79 & 7.50 & 0.37 \\
\hline $17-6,80$ & 1.05 & 0.14 & 76.25 & 0.28 & 3.94 & 0.05 & - & 0.05 & 3.84 & 11.73 & 2.62 \\
\hline $18-1,95$ & 0.25 & 0.03 & 86.45 & 0.14 & 5.26 & - & - & - & 1.37 & 6.41 & 0.19 \\
\hline $18-2,55$ & 0.41 & - & 80.18 & 0.59 & 6.95 & - & - & - & 3.25 & 8.04 & 0.59 \\
\hline $18-3,50$ & 0.45 & - & 82.37 & 0.31 & 5.02 & - & - & 0.04 & 1.06 & 10.34 & 0.17 \\
\hline $18-4,110$ & 1.40 & - & 81.70 & 0.23 & 5.69 & - & - & - & 4.87 & 5.69 & 0.31 \\
\hline $18-5,40$ & 2.43 & 0.04 & 75.92 & 0.28 & 6.20 & 0.04 & - & - & 0.73 & 13.20 & 1.10 \\
\hline $18-6,53$ & 0.17 & - & 88.46 & 0.17 & 2.88 & - & - & - & 0.55 & 7.29 & 0.50 \\
\hline $19-1,70$ & 0.70 & - & 81.73 & 0.31 & 5.13 & 0.04 & - & - & 0.29 & 11.23 & 0.40 \\
\hline $19-2,70$ & 2.78 & - & 79.95 & 0.10 & 3.57 & - & - & - & 0.56 & 11.59 & 1.24 \\
\hline $19-3,60$ & 5.78 & - & 64.74 & 0.16 & 4.54 & - & - & - & 1.18 & 18.69 & 4.89 \\
\hline $19-4,23$ & 3.15 & 0.05 & 82.45 & 0.47 & 5.13 & - & - & - & 3.63 & 4.42 & 0.36 \\
\hline $19-5,29$ & 3.92 & - & 78.79 & 0.46 & 3.21 & - & - & - & 6.54 & 6.97 & 0.10 \\
\hline $19-6,27$ & 1.53 & - & 84.25 & 0.20 & 3.89 & - & - & - & 2.61 & 7.33 & 0.12 \\
\hline $20-1,40$ & 0.53 & - & 91.17 & 0.08 & 3.29 & - & - & - & 1.13 & 3.76 & 0.04 \\
\hline $20-2,40$ & 0.52 & - & 93.65 & 0.06 & 2.99 & - & - & - & 0.26 & 2.38 & 0.11 \\
\hline $20-3,40$ & 1.55 & - & 88.35 & 0.05 & 2.95 & - & - & - & 3.20 & 3.64 & 0.04 \\
\hline $20-4,40$ & 3.33 & 0.04 & 83.61 & 0.31 & 4.21 & - & - & - & 3.09 & 5.37 & - \\
\hline $20-5,40$ & 0.47 & - & 86.83 & 0.39 & 3.13 & - & - & 0.04 & 0.32 & 8.22 & 0.57 \\
\hline $20-6,40$ & 0.82 & - & 92.08 & 0.06 & 3.43 & - & - & - & 0.15 & 3.29 & 0.19 \\
\hline $21-1,40$ & 4.05 & - & 81.66 & 0.12 & 2.44 & - & - & - & 0.24 & 11.23 & 0.24 \\
\hline $21-2,80$ & 5.59 & 0.03 & 84.35 & 0.45 & 4.00 & - & - & - & 0.40 & 4.82 & 0.21 \\
\hline $21-3,25$ & 4.74 & - & 83.81 & 0.36 & 4.41 & - & - & 0.07 & 2.53 & 2.76 & 1.19 \\
\hline $21-4,85$ & 9.20 & - & 82.85 & 0.14 & 2.68 & - & - & 0.08 & 1.65 & 1.58 & 1.32 \\
\hline $21-5,80$ & 4.68 & 0.11 & 86.11 & 0.19 & 2.95 & - & - & - & 0.94 & 4.97 & 0.11 \\
\hline $21-6,80$ & 2.02 & - & 30.02 & 0.04 & 2.23 & 3.69 & 3.50 & 0.99 & 2.85 & 3.25 & 51.25 \\
\hline $22-1,80$ & 2.86 & - & 86.22 & 0.09 & 3.58 & - & - & - & 0.71 & 5.31 & 1.06 \\
\hline $22-1,80$ & 2.39 & - & 90.35 & 0.21 & 4.20 & - & - & - & 0.25 & 1.87 & 0.57 \\
\hline $22-3,87$ & 2.39 & - & 80.76 & 0.30 & 4.48 & 0.05 & - & - & 0.60 & 10.53 & 0.87 \\
\hline $22-4,80$ & 2.79 & 0.05 & 90.90 & 0.28 & 2.71 & - & - & - & 0.36 & 2.37 & 0.32 \\
\hline $22-5,80$ & 1.90 & - & 60.86 & 0.17 & 2.17 & 0.86 & 2.37 & 0.56 & 0.09 & 1.85 & 28.87 \\
\hline $22-6,80$ & 4.88 & - & 85.54 & 0.21 & 3.03 & - & 0.09 & - & 0.51 & 5.52 & 0.22 \\
\hline $23-1,80$ & 2.02 & - & 89.61 & 0.10 & 2.60 & - & - & 0.08 & 1.15 & 4.20 & 0.16 \\
\hline $23-2,80$ & 1.08 & - & 90.29 & 0.30 & 3.14 & - & - & - & 0.28 & 4.62 & 0.28 \\
\hline $23-3,80$ & 1.15 & - & 44.47 & 0.08 & 3.47 & 1.80 & 4.01 & 0.64 & 0.32 & 1.06 & 43.35 \\
\hline $23-4,80$ & 1.35 & 0.04 & 87.35 & 0.22 & 3.92 & - & - & - & 1.66 & 4.73 & 0.36 \\
\hline $23-5,86$ & 0.44 & - & 83.41 & 0.17 & 2.57 & - & - & - & 0.32 & 12.54 & 0.51 \\
\hline $24-1,80$ & 0.22 & - & 87.53 & 0.44 & 2.03 & - & - & 0.04 & 0.27 & 7.66 & 1.83 \\
\hline $24-2,80$ & 0.15 & - & 92.64 & 0.18 & 1.60 & - & - & - & 0.49 & 4.10 & 0.81 \\
\hline $24-3,80$ & 0.04 & - & 92.49 & 0.04 & 1.75 & - & - & 0.04 & 0.18 & 5.15 & 0.15 \\
\hline $24-4,80$ & 0.28 & - & 83.20 & 0.27 & 3.63 & - & - & 0.03 & 0.09 & 11.21 & 1.31 \\
\hline $24-5,80$ & 0.34 & - & 90.85 & 0.21 & 3.44 & - & - & 0.04 & 0.08 & 4.72 & 0.37 \\
\hline $24-6,80$ & 0.24 & - & 91.47 & 0.38 & 3.07 & 0.04 & - & 0.08 & 0.24 & 3.39 & 1.07 \\
\hline $25-1,95$ & - & - & 91.85 & 0.13 & 3.77 & - & - & - & 0.41 & 3.38 & 0.20 \\
\hline $25-4,130$ & 0.04 & - & 84.00 & 0.36 & 3.68 & - & - & - & 0.47 & 10.84 & 0.61 \\
\hline $25-5,90$ & 0.04 & - & 93.75 & 0.19 & 1.82 & - & - & - & 0.54 & 3.66 & 0.04 \\
\hline $26-1,80$ & - & - & 82.34 & 0.02 & 7.56 & - & - & - & 0.28 & 9.49 & 0.33 \\
\hline $26-2,80$ & - & - & 78.08 & 0.33 & 7.46 & - & - & 0.04 & 0.52 & 12.90 & 0.57 \\
\hline $26-3,80$ & - & - & 83.69 & 0.33 & 3.63 & - & - & - & 0.04 & 12.01 & 0.28 \\
\hline
\end{tabular}


TABLE 1 - Continued

\begin{tabular}{|c|c|c|c|c|c|c|c|c|c|c|c|}
\hline $\begin{array}{l}\text { Sample No. } \\
\text { (Interval in } \mathrm{cm} \text { ) }\end{array}$ & Radiol. & Diat. & P1. For. & Fish d. & Benthics & Relict m. & Phosph. & Glauc. & Volc. m. & Pyrite & Terrig. m. \\
\hline $26-4,80$ & - & - & 89.90 & 0.32 & 3.33 & - & - & - & 0.52 & 5.51 & 0.33 \\
\hline $26-5,80$ & - & - & 88.33 & 0.43 & 4.01 & 0.06 & - & - & 0.42 & 5.17 & 1.55 \\
\hline $26-6,80$ & - & - & 92.02 & 0.46 & 3.75 & - & - & 0.08 & 0.38 & 2.73 & 0.50 \\
\hline $27-1,80$ & - & - & 97.03 & 0.05 & 1.12 & - & - & - & 0.12 & 1.14 & 0.05 \\
\hline $27-2,80$ & - & - & 88.69 & 0.05 & 0.98 & - & - & - & 0.04 & 10.15 & 0.04 \\
\hline $27-3,80$ & - & - & 89.94 & 0.47 & 3.09 & - & - & - & 0.63 & 5.58 & 0.29 \\
\hline $27-4,80$ & - & - & 91.46 & 0.46 & 2.06 & - & - & 0.05 & 0.83 & 4.72 & 0.43 \\
\hline $27-5,80$ & - & - & 92.24 & 0.80 & 2.96 & - & - & - & 0.63 & 2.92 & 0.44 \\
\hline $28-1,80$ & - & - & 70.82 & 0.45 & 10.94 & 0.05 & - & - & 0.37 & 17.19 & 0.10 \\
\hline $28-2,85$ & - & - & 80.97 & 0.36 & 6.07 & - & - & - & 0.04 & 10.16 & 2.28 \\
\hline $28-3,82$ & - & - & 77.57 & 0.59 & 9.42 & - & - & - & 0.24 & 8.96 & 3.14 \\
\hline $28-4,80$ & - & - & 78.31 & 0.59 & 13.63 & - & 0.03 & - & 0.59 & 4.37 & 2.37 \\
\hline $28-5,80$ & - & - & 57.46 & 0.60 & 10.43 & - & - & - & 0.49 & 29.55 & 1.41 \\
\hline $29-1,70$ & - & - & 93.36 & 0.19 & 1.62 & - & - & - & 0.50 & 1.11 & 0.18 \\
\hline $29-2,72$ & - & - & 83.61 & 0.91 & 5.71 & - & - & 0.04 & 0.35 & 5.60 & 3.52 \\
\hline $29-3,75$ & - & - & 93.28 & 0.44 & 3.49 & - & - & - & 0.24 & 2.03 & 0.48 \\
\hline $29-5,70$ & - & - & 83.83 & 0.25 & 8.31 & - & - & - & 0.22 & 6.90 & 0.47 \\
\hline $30-1,70$ & - & - & 92.15 & 0.16 & 3.81 & - & 0.04 & 0.04 & 0.11 & 2.86 & 0.68 \\
\hline $30-2,70$ & - & - & 91.89 & 0.14 & 3.35 & - & - & - & 0.12 & 4.40 & 0.16 \\
\hline $30-3,70$ & - & - & 95.07 & 0.33 & 2.09 & - & - & - & 0.22 & 2.18 & 0.11 \\
\hline $30-4,70$ & - & - & 90.66 & 0.43 & 3.78 & - & - & - & 0.09 & 4.90 & 0.13 \\
\hline $30-5,70$ & - & - & 78.70 & 0.61 & 4.71 & - & - & 0.04 & 0.20 & 15.42 & 0.33 \\
\hline $30-6,70$ & - & - & 95.28 & 0.10 & 1.91 & - & - & - & 0.21 & 2.32 & 0.14 \\
\hline $31-1,70$ & - & - & 88.73 & 0.72 & 4.69 & - & - & 0.03 & 0.03 & 5.38 & 0.45 \\
\hline $31-2,70$ & - & - & 94.57 & 0.29 & 2.87 & - & - & - & 0.07 & 2.13 & 0.07 \\
\hline $31-3,70$ & - & - & 94.04 & 0.27 & 2.21 & - & - & - & 0.15 & 3.18 & 0.11 \\
\hline $31-4,70$ & - & - & 93.12 & 0.17 & 2.36 & - & - & - & 0.14 & 3.73 & 0.48 \\
\hline $32-1,70$ & - & - & 87.35 & 0.31 & 2.76 & - & - & - & 4.54 & 4.27 & 0.71 \\
\hline $32-2,70$ & - & - & 95.19 & 0.15 & 1.66 & - & - & - & 0.40 & 2.21 & 0.30 \\
\hline $32-3,70$ & - & - & 92.56 & 0.39 & 2.82 & - & - & - & 0.62 & 3.40 & 0.21 \\
\hline $32-4,70$ & - & - & 95.12 & 0.22 & 2.45 & - & - & - & 0.21 & 1.92 & 0.05 \\
\hline $33-1,70$ & - & - & 96.64 & 0.26 & 1.45 & - & - & - & 0.34 & 1.19 & 0.11 \\
\hline $33-2,70$ & - & - & 92.50 & 0.20 & 1.47 & - & - & - & 3.40 & 2.15 & 0.27 \\
\hline $33-3,65$ & - & - & 94.84 & 0.36 & 2.16 & - & - & - & 1.95 & 0.25 & 0.36 \\
\hline $33-4,70$ & - & - & 91.63 & 0.42 & 1.97 & - & - & - & 0.63 & 4.84 & 0.51 \\
\hline $34-1,68$ & - & - & 96.34 & 0.12 & 2.15 & - & - & - & 0.20 & 1.18 & - \\
\hline $34-2,70$ & - & - & 94.45 & 0.13 & 2.21 & - & - & - & 1.09 & 1.55 & 0.56 \\
\hline $34-3,70$ & - & - & 97.71 & 0.15 & 1.23 & - & - & - & 0.37 & 0.39 & 0.13 \\
\hline $34-4,70$ & - & - & 95.76 & 0.04 & 1.27 & - & - & - & 0.34 & 2.34 & 0.21 \\
\hline $34-5,40$ & - & - & 95.15 & 0.32 & 1.86 & - & - & - & 0.23 & 2.12 & 0.31 \\
\hline $34-6,60$ & - & - & 97.63 & 0.15 & 1.65 & - & - & - & 0.28 & 0.29 & - \\
\hline $34-7,40$ & - & - & 96.89 & 0.43 & 1.52 & - & - & - & 1.02 & 0.09 & 0.04 \\
\hline $36-1,70$ & - & - & 94.46 & 0.06 & 1.54 & - & - & 0.04 & 0.93 & 2.64 & 0.48 \\
\hline $36-2,75$ & - & - & 96.57 & 0.10 & 1.65 & - & - & - & 0.23 & 1.40 & - \\
\hline $37-1,70$ & - & - & 93.58 & 0.49 & 4.07 & - & - & - & 1.27 & 0.26 & 0.24 \\
\hline $37-2,70$ & - & - & 94.61 & 0.50 & 3.73 & - & - & - & 0.82 & 0.21 & 0.05 \\
\hline $37-3,70$ & - & - & 94.91 & 0.48 & 3.39 & - & - & 0.04 & 0.63 & 0.32 & 0.17 \\
\hline $37-4,85$ & - & - & 97.21 & 0.32 & 1.19 & - & - & - & 0.20 & 1.04 & 0.04 \\
\hline $38-1,70$ & - & - & 89.34 & 0.67 & 4.39 & - & - & - & 3.23 & 1.04 & 0.28 \\
\hline $38-2,71$ & - & - & 89.38 & 0.27 & 4.25 & - & - & - & 5.27 & 0.61 & 0.21 \\
\hline $38-3,89$ & - & - & 95.67 & 0.32 & 1.99 & - & - & - & 0.81 & 1.17 & - \\
\hline $38-4,90$ & - & - & 96.72 & 0.30 & 1.68 & - & - & - & 0.58 & 0.67 & - \\
\hline $38-5,70$ & - & - & 96.20 & 0.21 & 1.84 & - & - & - & 0.54 & 1.17 & 0.04 \\
\hline $38-6,110$ & - & - & 83.81 & 0.53 & 3.94 & 0.13 & 0.14 & 0.19 & 1.09 & 2.50 & 7.65 \\
\hline $39-1,70$ & - & - & 95.66 & 0.40 & 2.25 & - & - & - & 0.77 & 0.62 & 0.28 \\
\hline $39-2,71$ & - & - & 94.37 & 0.36 & 3.02 & - & - & - & 1.08 & 0.93 & 0.20 \\
\hline $39-3,75$ & - & - & 86.64 & 0.40 & 5.58 & 0.05 & 0.05 & 0.05 & 1.46 & 1.80 & 3.92 \\
\hline $39-4,100$ & - & - & 93.47 & 0.51 & 3.65 & - & - & 0.04 & 1.05 & 0.89 & 0.34 \\
\hline $39-5,80$ & - & - & 86.68 & 0.37 & 3.31 & - & - & 0.05 & 1.53 & 7.01 & 1.06 \\
\hline $41-3,70$ & - & - & 93.73 & 0.40 & 2.76 & - & - & - & 1.83 & 0.42 & 0.71 \\
\hline $41-5,80$ & - & - & 93.82 & 0.28 & 2.07 & - & - & - & 1.52 & 2.04 & 0.25 \\
\hline $41-6,70$ & - & - & 90.85 & 0.20 & 2.68 & - & - & 0.15 & 2.93 & 0.91 & 1.20 \\
\hline $42-2,140$ & - & - & 80.28 & 0.67 & 12.05 & - & - & 0.05 & 2.62 & 1.62 & 2.64 \\
\hline $43-2,70$ & - & - & 86.99 & 0.72 & 7.98 & - & - & 0.05 & 1.79 & 0.70 & 1.68 \\
\hline $43-4,70$ & - & - & 88.19 & 0.60 & 4.20 & - & - & - & 0.61 & 6.02 & 0.20 \\
\hline $43-5,80$ & - & - & 94.42 & 0.17 & 2.61 & - & - & - & 0.33 & 2.31 & 0.12 \\
\hline $43-6,70$ & - & - & 89.72 & 0.68 & 5.62 & - & - & - & 0.42 & 3.42 & 0.12 \\
\hline $44-1,20$ & - & - & 83.60 & 0.60 & 7.52 & - & 0.05 & 0.05 & 0.71 & 4.07 & 3.38 \\
\hline $44-2,70$ & - & - & 90.76 & 0.52 & 5.92 & - & - & - & 0.67 & 1.18 & 0.84 \\
\hline
\end{tabular}


TABLE 1 - Continued

\begin{tabular}{|c|c|c|c|c|c|c|c|c|c|c|c|}
\hline $\begin{array}{l}\text { Sample No. } \\
\text { (Interval in } \mathrm{cm} \text { ) }\end{array}$ & Radiol. & Diat. & Pl. For. & Fish d. & Benthics & Relict m. & Phosph. & Glauc. & Volc. m. & Pyrite & Terrig. $\mathrm{m}$. \\
\hline $44-3,80$ & - & - & 92.70 & 0.49 & 3.03 & - & - & 0.04 & 0.30 & 2.89 & 0.52 \\
\hline $44-4,70$ & - & - & 96.38 & 0.07 & 1.74 & - & - & - & 0.11 & 1.62 & - \\
\hline $44-5,70$ & - & - & 74.66 & 1.00 & 4.99 & - & - & 0.06 & 0.41 & 15.94 & 2.81 \\
\hline $45-1,70$ & - & - & 90.02 & 0.42 & 4.43 & - & - & - & 0.51 & 4.46 & 0.20 \\
\hline $45-2,70$ & - & - & 80.69 & 1.41 & 12.14 & - & - & - & 2.45 & 2.13 & 1.17 \\
\hline $45-3,70$ & - & - & 73.87 & 1.73 & 13.81 & - & - & - & 3.72 & 5.75 & 1.04 \\
\hline $45-4,70$ & - & - & 50.43 & 1.71 & 16.62 & 0.06 & - & 0.06 & 1.99 & 25.68 & 3.34 \\
\hline $45-5,70$ & - & - & 65.74 & 0.61 & 12.02 & - & - & 0.12 & 0.58 & 18.73 & 1.99 \\
\hline $47-1,70$ & - & - & 91.54 & 0.42 & 5.06 & - & - & - & 1.02 & 1.75 & 0.20 \\
\hline $47-2,70$ & - & - & 86.81 & 0.66 & 5.84 & 0.04 & - & - & 2.04 & 4.40 & 0.23 \\
\hline $47-3,70$ & - & - & 92.99 & 0.46 & 2.14 & 0.08 & - & - & 0.57 & 3.68 & 0.08 \\
\hline $47-4,70$ & - & - & 91.21 & 0.63 & 4.02 & 0.04 & - & - & 0.84 & 2.98 & 0.23 \\
\hline $47-5,70$ & - & - & 93.81 & 0.58 & 2.51 & - & - & - & 0.36 & 2.63 & 0.12 \\
\hline $48-1,70$ & - & - & 94.92 & 0.30 & 2.27 & - & 0.04 & - & 0.72 & 1.45 & 0.28 \\
\hline $48-2,70$ & - & - & 82.53 & 0.80 & 5.54 & - & - & 0.05 & 0.98 & 9.14 & 0.92 \\
\hline $48-3,34$ & - & - & 84.74 & 0.42 & 3.38 & - & - & - & 0.16 & 11.25 & 0.04 \\
\hline $48, \mathrm{CC}$ & - & - & 89.84 & 1.21 & 4.16 & - & - & - & 0.72 & 3.81 & 0.19 \\
\hline $49-1,70$ & - & - & 84.31 & 0.50 & 4.97 & - & 0.05 & - & 1.20 & 7.53 & 1.39 \\
\hline $49-2,70$ & - & - & 95.46 & 0.27 & 2.27 & - & - & - & 0.49 & 0.30 & 0.30 \\
\hline $49-3,70$ & - & - & 91.70 & 0.39 & 3.22 & - & - & - & 0.87 & 3.65 & 0.24 \\
\hline $50-1,86$ & - & - & 82.36 & 1.47 & 6.04 & - & - & - & 4.56 & 4.25 & 1.30 \\
\hline $51, \mathrm{CC}$ & - & - & 48.52 & 1.28 & 9.09 & 0.26 & 0.03 & 0.05 & 6.80 & 30.57 & 2.67 \\
\hline $52-1,69$ & - & - & 67.87 & 1.69 & 9.15 & - & - & - & 2.05 & 18.59 & 0.65 \\
\hline $52-2,72$ & - & - & 35.17 & 1.32 & 12.78 & - & - & 0.24 & 1.46 & 33.96 & 13.51 \\
\hline $52-3,61$ & - & - & 71.04 & 1.80 & 5.43 & - & - & - & 1.21 & 16.53 & 4.00 \\
\hline $52-4,70$ & - & - & 82.97 & 2.50 & 6.42 & - & 0.06 & 0.06 & 2.80 & 4.36 & 0.62 \\
\hline $52-5,70$ & - & - & 45.50 & 3.26 & 9.08 & - & - & - & 2.24 & 37.10 & 2.27 \\
\hline $52-6,70$ & - & - & 51.17 & 2.78 & 8.51 & - & - & 0.23 & 5.15 & 28.26 & 3.12 \\
\hline $53-1,70$ & - & - & 51.41 & 3.95 & 18.07 & - & - & 0.17 & 4.35 & 20.20 & 0.98 \\
\hline $54-1,70$ & - & - & 75.21 & 2.18 & 8.04 & - & - & 0.16 & 5.26 & 7.99 & 0.99 \\
\hline $54-2,70$ & - & - & 57.23 & 1.32 & 4.47 & - & - & 0.14 & 2.38 & 30.83 & 1.67 \\
\hline $54-3,80$ & - & - & 59.88 & 2.03 & 9.74 & - & - & 0.05 & 4.53 & 20.36 & 2.72 \\
\hline $54-4,70$ & - & - & 77.55 & 1.05 & 4.12 & - & - & - & 0.75 & 15.83 & 0.44 \\
\hline $54-5,70$ & - & - & 86.45 & 1.43 & 3.77 & - & - & 0.19 & 2.28 & 5.38 & 0.47 \\
\hline $54-6,40$ & - & - & 91.47 & 0.76 & 3.11 & - & - & - & 1.08 & 3.41 & 0.17 \\
\hline $55-1,70$ & - & - & 86.35 & 1.18 & 4.25 & - & - & - & 0.86 & 7.36 & - \\
\hline $55-2,69$ & - & - & 49.74 & 1.74 & 6.83 & - & - & 0.05 & 4.92 & 35.28 & 1.44 \\
\hline $55-3,70$ & - & - & 86.18 & 1.13 & 3.55 & - & - & 0.05 & 3.00 & 4.80 & 1.29 \\
\hline $55-4,70$ & - & - & 86.48 & 0.30 & 1.93 & - & - & 0.15 & 3.30 & 5.55 & 2.30 \\
\hline $55-5,70$ & - & - & 87.28 & 0.50 & 2.47 & - & - & 0.04 & 2.24 & 7.12 & 0.28 \\
\hline $56-1,69$ & - & - & 87.60 & 0.61 & 2.77 & - & - & - & 4.04 & 4.59 & 0.39 \\
\hline $56-2,70$ & - & - & 83.34 & 0.30 & 2.26 & - & - & - & 5.12 & 7.44 & 1.57 \\
\hline $56-3,44$ & - & - & 37.04 & 0.31 & 3.47 & - & - & 0.23 & 8.35 & 48.90 & 0.39 \\
\hline
\end{tabular}

to 29 , they increase up to 14 per cent; in Cores 30 through 36 , they are lowest ( 1 to $2 \%$ ). Highest values (up to 26\%) occur in Cores 45, 52, and 53. In Cores 2 through 15 , nearly each increase in benthic foraminifers, even the smallest one, correlates to an increase in the radiolarian/planktonic foraminifer ratio. Especially, the four radiolarian maxima in Sections 8-4, 9-2, $10-3$, and $14-6$ to $15-2$ are clearly reflected in an increase in benthics. The same observation results from per cent values of radiolarians and benthic foraminifers (Table 1). The good correlation is not due to the fact that, in both cases, the ratio is formed with planktonic foraminifers. Production of planktonic foraminifers increases under the influence of strong upwelling (Diester-Haass, 1976b). In these samples where high fertility was probable, both benthic/planktonic ratios of foraminifers and radiolarian/plankton foraminifer ratios increase; this suggests that the increase in accumulation rate of benthic foraminifers and radiolarians is greater than that of planktonic foraminifers.
The high benthic-planktonic ratios in Cores 25 to 29,37 to 39,42 to 45 , and 52 to 56 are correlated with the presence of pelecypods and serpulidae. The latter forms are normally not found in water depths of 3000 meters such as exist at Site 397. In the layers with minimum benthic values in Cores 32 to 36 , however, none or nearly none of these shells were found.

The correlation of benthic/planktonic ratios of foraminifers to fragmentation of planktonic foraminifers is not clear, contrary to results from Sites 366 and 369 (Diester-Haass, 1978a).

Benthic/planktonic ratios should be about one per cent in this water depth of about 3000 meters, after Lutze (this volume). Benthic/planktonic values in recent sediments from 3000 meter water depths off northwest Africa $\left(21\right.$ to $\left.23^{\circ} \mathrm{N}\right)$ are about 1.3 per cent in regions without strong upwelling and about 3 per cent in highly fertile areas (Diester-Haass, 1978b). The much higher values encountered in several intervals at Site 397 point either to higher production, or to 
a shallow water sediment supply or to preferential dissolution of planktonic foraminifers leading to the enrichment of benthic forms.

\section{Terrigenous Material}

The amount of terrigenous material such as quartz, mica, "other minerals" (such as feldspar, dolomite, and dark minerals) is plotted in Figure 1j. Two kinds of quartz were counted: colorless quartz and quartz with yellowish reddish iron-oxide staining.

No quartz grains with red-colored clay coating or red clay aggregates were found. The ratio (red quartz/ colorless quartz) $\times 100$ is called the desert quartz number (cf. Radcewski, 1937). The stained quartz grains come from desert regions (Walker, 1967; Norris, 1969; Diester-Haass et al., 1973; and DiesterHaass, 1976a).

The amount of terrigenous material in the $>63 \mu \mathrm{m}$ fraction is 10 per cent (except for a few coarse-grained layers where it increases up to $50 \%$ ). In the 40 to 63 $\mu \mathrm{m}$ fraction, it increases up to 50 per cent. Variations in amount of terrigenous components are parallel in both fractions. The curve showing variations in amount of terrigenous material and in desert quartz number (Figure $1 \mathrm{k}$ along the core profile can be divided into the five intervals which follow:

1) Cores 2 through 10 . Strong variations between 50 and $<5$ per cent of terrigenous material in the 40 to $63 \mu \mathrm{m}$ fraction. Desert quartz numbers vary between $<20$ (in layers with high terrigenous input) and up to 100 (where terrigenous material is rare).

2 ) Core 11 to Section 21-5. The layers with small amounts (generally $<20 \%$ ) are longer, variations are smaller. Desert quartz numbers are generally $>20$.

3) Section 21-5 to Core 23. Several variations between layers with very small amounts $(<5 \%)$ and very coarse grained terrigenous input (up to $50 \%$ in the sand fraction). Desert quartz numbers are $>30$.

4) Cores 24 through 42 . Relatively homogeneous section with small terrigenous input in fractions $>40$ $\mu \mathrm{m}$. There are only a few layers with an increase in terrigenous material. Desert quartz numbers are $>30$.

$5)$ Cores 43 through 56 . Strong variations between high $(20$ to $70 \%)$ and small $(<5 \%)$ values of terrigenous material. Desert quartz numbers vary correspondingly: $<20$ to 70 .

\section{Glauconite, Relict Particles}

The curve showing variations in amount of glauconite (Figure 11 in the 40 to 63 and $>63 \mu \mathrm{m}$ fractions resembles that of terrigenous material. In Core 2 to Section 15-2, the layers with high terrigenous input contain up to 1.8 per cent glauconite in the $>40 \mu \mathrm{m}$ fraction. Layers with low terrigenous input have no glauconite. In the Pliocene-Miocene section of Site 397, glauconite is absent where terrigenous supply is low. Where the supply increases, glauconite is present, often in low amounts of about 0.2 per cent of the 40 to 63 $\mu \mathrm{m}$ fraction. This indicates that supply was derived from shallow water. Higher terrigenous material values in Cores 52 to 56 are correlated with glauconite amounts up to 1 per cent of the 40 to $63 \mu \mathrm{m}$ fraction.
Relict particles are components which presumably are not contemporaneous with sedimentation conditions at the site. They probably were derived from shallow water, because they are abraded, bored, blackened and sometimes glauconitized shells, mainly of molluscs, or sometimes of benthic foraminifers. Relict particles are even rarer than glauconite (Figure $1 \mathrm{~m})$. In the Quaternary section, they form 0 to 0.6 per cent (one value of $1.7 \%$ ) of the 40 to 63 and $>63 \mu \mathrm{m}$ fraction in those layers where glauconite and terrigenous components are important constitutents. In the Pliocene-Miocene sequence, relict particles generally (but not in all layers) are present only in a few coarsegrained samples with high glauconite values, e.g., Sections 21-6 (with 3.7\%), 22-5, and 23-3. In Cores 54 to 56 , glauconite and terrigenous material form high amounts without the presence of relict particles.

\section{Volcanic Material}

Volcanic material was found mainly as yellowish brownish volcanic glass. Multicolored volcanic ash is rare. There are three layers with abundant volcanic material (Figure 1n): Samples 2-3, 5-7 cm and 13-16 $\mathrm{cm}$, with up to 50 per cent volcanic material in the 40 to $63 \mu \mathrm{m}$ fraction and up to 25 per cent in the sand fraction; Cores 17 to 21 , with values between 0 and 10 per cent; and Cores 22 to 49 , where volcanic input is low $(<5 \%)$, increasing up to about 10 per cent in Cores 52 to 56 .

\section{Pyrite}

Pyrite occurs in three forms: (1) small, long tubes, probably burrow casts; (2) foraminiferal fillings; and (3) clumps without a definite shape. Their grain size increases with depth at the site. Amounts of pyrite (Figure 1o) increase continuously from $<5$ per cent in the upper part, to up to 15 per cent in Core 29. In Cores 32 through 42 , values are less than 3 per cent of the sand fraction and increase again in Cores 43 to 56 up to 30 per cent. Pyrite maxima are not correlated to maxima in radiolarians or benthics.

\section{Fragmentation of Planktonic Foraminifers}

The calcareous tests of planktonic foraminifers break down under the influence of dissolution and thus become increasingly fragmented. The ratio of fragments to whole tests will increase with increasing dissolution (Arrhenius, 1952; Berger, 1970; Berger and von Rad, 1972; Diester-Haass, 1975b; and Diester-Haass, 1978a). The influence of dissolution on the tests is species dependent; there are very sensitive shells which are completely dissolved before others begin to break down. The ratio of (fragments/whole tests + fragments) $\times 100$ has been shown to be useful indicator of variations in $\mathrm{CaCO}_{3}$ dissolution, even when countings are made without distinguishing species (DiesterHaass, 1978a). The variations in fragmentation at Site 397 show a general increase from top to bottom of the investigated section (Figure 1p). This general increase can be divided into several subsequences:

1) Cores 2 through 15. A general increase in fragmentation is divided into five cycles with maxima inter- 
rupted by sharply limited short minimum zones. The maxima are in the following sections: $2-5$ to $5-3,6-4$ to $8-4,9-4$ to $10-6,12-1$ to $13-1$, and $14-3$ to $15-6$. The maximum values increase from 40 to 50 per cent (one value of $60 \%$ ). The minimum values increase downhole from 17 to about 35 per cent.

2 ) Cores 16 through 34 . Here maxima and minima are not as clearly defined. Only in the upper part (in Sections 20-2 to 20-6, 22-4 to 24-1, and 25-1 to 26-7), are there three maxima with values up to 55 per cent. In the lower part of this sequence, fragmentation varies between about 30 and 50 per cent without any trend.

3 ) Cores 36 through 56. Here maxima and minima are also not clearly defined. This may result from incomplete recovery and the consequent lack of more closely spaced samples. Maximum fragmentation values increase continuously in this interval from 55 to 75 per cent in Core 52.

As mentioned earlier, there is no clear correlation between fragmentation and benthic/planktonic ratios of foraminifers. If the latter were only dependent on varying dissolution of planktonic foraminifers, it should vary according to fragmentation values, because benthic foraminifers are more resistant to dissolution than planktonic forms and thus are enriched with increasing dissolution (Arrhenius, 1952). A perfect correlation between fragmentation and benthic/plankton ratios was found in Neogene sediments of Leg 41 (Diester-Haass, 1978a). By contrast, at Site 397, the two curves vary inversely from each other and (contrary to Leg 41 findings) an increase in benthics is correlated to a decrease in fragmentation (e.g., Sections 26-1 and 2, 28-4 and 5, $42-4$, and 54-3). This relationship might be due to a supply of benthic and planktonic foraminifers from the upper slope, where benthics are more abundant and planktonic forms are better preserved. A decision cannot be made regarding the extent to which the high benthic values in Core 52 are due to the strongest fragmentation being encountered there or to a shallow water sediment supply.

\section{DISCUSSION}

\section{Shallow Water Sediment Supply}

The study of shallow water sediment supply during the late Neogene is of interest at this site where the lower Miocene consists mainly of allochthonous material from shallow water. Did these processes of shallow water supply continue in the younger sequences, but on a smaller scale? The present continental slope in this area is steep and large-scale sliding and slumping processes during the late Quaternary are known (Embly, 1976; and Diester-Haass and Werner, in preparation). Perhaps the steep gradient also leads to a less dramatic supply of small amounts of upper slope material to the lower slope.

Indicators of shallow water sediment supply are glauconite, relict material, a strong increase in benthic/ planktonic ratios of foraminifers which cannot be explained by increased fertility or by dissolution changes, and the presence of debris of large pelecypods and serpulidae (living only in shallow water; van der Spoel, personal communication).

The depth of origin for such particles cannot be defined clearly but the upper slope in water depths of about 200 to 1000 meters is highly probable for the following reasons:

1) Typical shells from a shelf environment like benthic foraminifers (Lutze, this volume), bryozoens, corals, and gastropods are absent.

2) Glauconite and relict material, mainly in the size range up to $125 \mu \mathrm{m}$ (and rarely larger) have been found on the upper slope and outer shelf in glacial sediments from the upper Quaternary off northwestern Africa, but not on the deeper slope in depths below about 1000 meters (Diester-Haass, 1975a and unpublished results).

3) Thick-shelled pelecypods have been found off northwestern Africa in water depths down to about 1000 meters. In deeper water, only larvae and very thin-shelled mollusks were observed occasionally, if at all.

The problem and possible mechanism of shallow water sediment supply will be discussed first for the Quaternary sequence, Cores 2 to 15 . The layers in this sequence contain glauconite, relict material, and thick pelecypods, and also contain high amounts of terrigenous material and low desert quartz numbers (Figure 2 ). This is interpreted as the result of more humid conditions with rainfall and, thus, river supply. From up-

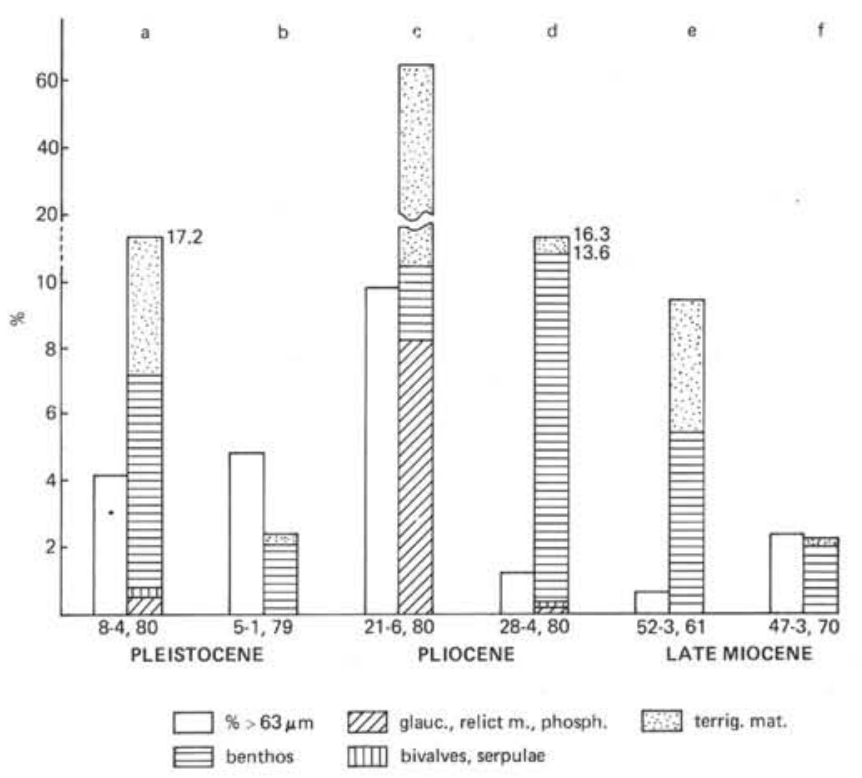

Figure 2. Size of sand fraction (in \%) of total sample weight and amount (\% of the $>63 \mu \mathrm{m}$ fraction) of terrigenous material, glauconite, relict material phosphorite grains, benthics, and bivalves and serpulides, in four typical layers with shallow water supply. (a) Quaternary, humid climate and high fertility; (b) Quaternary, arid climate; (c) Pliocene, supply of dune sand and shallow water particles; (d) Pliocene, supply of benthic foraminifers; (e) Late Miocene, humid climate; (f) Late Miocene, arid climate. 
per Quaternary sediments, it is known that these humid periods occured during glacial periods off northwestern Africa, north of $20^{\circ} \mathrm{N}$ (Diester-Haass, 1976a).

This correspondence between humid climate and glacial periods and, thus, lowered sea level is assumed to be the same for the early Quaternary. Consequently, these layers with shallow water particles are interpreted as being the result of increased circulation and stronger currents at the shelf break and upper slope during periods of lowered sea level. Shallow water facies are closer to the shelf break during such periods. Particles were brought into suspension either by waves or currents or burrowing organisms, a process that leads to particle by particle transport of shallow-water grains to the deeper slope, if downslope currents are present. In the upper Quaternary sediments, no rapid sedimentation processes such as turbidity currents intervened.

Benthic/planktonic ratios of foraminifers show only small-scale variations in the Quaternary. Some of the increases correlate with glauconite peaks, but these peaks also coincide with layers where fertility was high. Therefore, it cannot be determined whether increases in benthic foraminifers are due to higher productivity or a shallow water sediment supply, or both. The observation that in upper Quaternary sediments off northwestern Africa benthic/planktonic ratios increased where no shallow water sediment supply occurred but where strong upwelling is present (Diester-Haass, 1978b) favors the concept of fertility changes producing increased benthic/planktonic ratios.

At the Quaternary/Pliocene boundary, there is a sharp downward decrease in the amount of shallow water particles. If glauconite and relict particles are considered as indicators of shallow water sediment supply, this supply was considerably higher in the Quaternary than in the Pliocene (except for three distinct layers). If benthic foraminifers and serpulides are taken into account, there are some layers in the Pliocene and Miocene intervals exhibiting a greater shallow water sediment supply.

The intervals with a shallow water sediment supply in the Pliocene and Miocene intervals can be divided into three different types (Figure 2). It is not known whether these are thin distinctive layers or thicker units, because sample distribution (1 per section of 150 $\mathrm{cm}$ ) is too sparse. No radiographic study could be made; therefore, textural indicators defining the type of shallow water sediment supply are not available.

The first type is represented by three layers, Sections 21-6, 22-5, and 23-3, where terrigenous material in the coarse fractions increases up to about 50 per cent. Terrigenous material is more abundant in the coarse fractions $>63 \mu \mathrm{m}$ than in the 40 to $63 \mu \mathrm{m}$ fractions. Quartz grains, which are absent in the $>125 \mu \mathrm{m}$ fraction in the rest of the sediments, comprise up to 30 per cent of the 125 to $250 \mu \mathrm{m}$ fraction in these three layers. Sand fraction percentages increase up to 6,10 , and 14 per cent (Figure 2c).

Desert quartz numbers indicate an arid climate in the three layers. Benthic components are not markedly enriched, Relict material, however, has highest values (up to $3.7 \%$ ) and glauconite is distinctly increased (although absolute values are quantitatively not important for the sediment composition, 0.6 to $1 \%$ of the sand fraction). Phosphorite grains, probably reworked from older strata (Diester-Haass, 1978a) form 2 to 3 per cent of the sand fraction (see Appendix, this chapter, for interpretation and additional results).

The second type of layers with shallow water sediment supply are those where the benthic/planktonic ratios of foraminifers increase drastically, from $<5$ to 8 in Sections 26-1 and 26-2, up to 14 in Sections 28-1 to 28-5, and 42-2 (Figure 1i). No indication as to high fertility and to strong $\mathrm{CaCO}_{3}$ dissolution of planktonic foraminifers could be found. Ater Lutze (this volume), the normal amount of benthic foraminifers at the water depth at Site 397 would be about 1 per cent of total foraminifer amounts. These layers with increased benthic values are in the lower Pliocene. They also contain serpulidae: 0.5 to 1.2 per cent of the sand fraction; but, again, are quantitatively negligible amounts. Their presence, however, indicates that a shallow water sediment supply was active and that currents had been vigorous because serpulidae range to $500 \mu \mathrm{m}$ in size.

In addition to these prominent layers, there is a good visual correlation between benthic/planktonic ratios of foraminifers and serpulidae in all the Pliocene. In Sections 29-3 to 31-4, serpulidae and some pelecypods are present and benthic/planktonic ratios are higher than in Cores 32 to 36 , where benthic/ planktonic ratios are lowest and no serpulidae are present. In Cores 37 to 39 , the presence of serpulidae is again linked to increased benthic/planktonic ratios. In these cores, glauconite and relict material do not increase.

Desert quartz numbers indicate an arid climate for all the early Pliocene. There is, however, a certain correlation between amount of terrigenous material and benthic particles, as in the interval without serpulidae and lowest benthonic/planktonic ratios (Cores 32 to 36). Terrigenous material also has lowest percentages in these cores. It is therefore presumed that together with the benthic materials, some quartz grains also came downslope. In Sections 38-6 and 39-3, benthic increases coincide with higher amounts of quartz grains not only in the 40 to $63 \mu \mathrm{m}$ fraction, but also in the $>63 \mu \mathrm{m}$ fraction, indicating a rather strong downslope transport.

The transport mechanism of the benthic particles and quartz grains is not well understood. Perhaps the steepness of the slope enables the shallow water particles to slide down slope after having been brought into suspension either by burrowing organisms or by currents. Textural analyses would help to determine the effectiveness of either mass transport or particle by particle transport. Mass transport, however, is unlikely because the amount of shallow water particles $>40 \mu \mathrm{m}$ as a per cent of the total sediment is small $(<1 \%)$.

The third type of layers with indication of shallow water sediment supply is found in the upper Miocene sequence in Sections 44-1 and 2, 44-5, 45-4, 48-2, 52-2 
and $3,52-5$ to $53-1,54-3$, and $55-2$ to $55-4$. These layers have in common glauconite values up to 0.6 per cent in Cores 44 to 49 and up to 1 per cent in Cores 52 to 55 in the 40 to $63 \mu \mathrm{m}$ fraction. Serpulidae occur in small amounts (generally $0.2 \%$ of the sand fraction). Each glauconite peak corresponds to a peak in benthic/planktonic ratios (Figure 2e). Their absolute values are in the same order of magnitude as in the Quaternary section, except for three samples where they increase drastically up to 25 per cent (Cores 45-4, 52-2, and 53-1). These values do not correlate with the highest fragmentation values of planktonic foraminigers and, thus, are not due to enrichment of benthics by dissolution. Terrigenous material in the 40 to 63 and $>63 \mu \mathrm{m}$ fractions increases in these layers (up to $20 \%$ in the 40 to $63 \mu \mathrm{m}$ fraction including three samples with 35,70 , and $25 \%$ ). Desert quartz numbers are $<20$. These facts indicate a humid climate.

These layers, with increased shaliow water sediment supply like those in the Quaternary, may have occurred during humid periods when sea level was lowered perhaps 40 meters during the latest Miocene (cf. Shackleton and Kennett, 1975b), and transport of shallow water particles was enhanced. The lowered sea level might be due to Antarctic glaciations, after Shackleton and Kennett (1975a). Antarctic glaciers had reached their actual extent at the beginning of the late Miocene. Investigations at nearby Site 369 also led to the conclusion that, as in the Quaternary, late Miocene climatic changes occurred between humid and arid climate (Diester-Haass, 1978a).

The explanation poses one problem. Increased benthic/planktonic ratios in the Quaternary were explained mainly by increased fertility due to upwelling. In the late Miocene, no upwelling occurred and benthic amounts supplied from shallow water reached anomalously high values. Perhaps most of the quartz grains were also supplied from shallow water and, similar to the benthic and glauconite fractions, do not reflect climatic changes. Reworking of older strata might lead to a supply of unstained quartz grains, thus negating climatic conclusions. Consequently, interpretation of a shallow water sediment supply also becomes erroneous. However, because Site 369 did not have a significant shallow water sediment supply, this possiblity is unlikely.

The presence of shallow water particles indicates that during nearly all of Neogene time, there was sediment transport from the upper slope to the lower slope. The amount of sand-sized shallow water particles is never significant relative to the total sediment composition (except for the three samples in Cores 21, 22, and 23). The presence of these particles, does however, indicate small-scale down-slope transport processes on this rather steep slope, which became extremely strong in the early Miocene.

\section{Climate}

The amount and grain size of terrigenous particles $>40 \mu \mathrm{m}$ and desert quartz numbers can give indications of climatic variations on the nearby continent.
Climatic variations in northwestern Africa during the later Quaternary have been detected by analysis of the terrigenous material in the coarse fraction from sediment cores off northwestern Africa (Diester-Haass et al., 1973; Diester-Haass, 1975a, 1976a). In northwestern Africa $\left(20^{\circ}\right.$ to $\left.27^{\circ} \mathrm{N}\right)$, Holocene and older interglacial periods had an arid climate with mainly wind transport of the terrigenous particles. During glacial periods, the climate was humid in northwestern Africa (north of $20^{\circ} \mathrm{N}$ ) and rivers transported terrigenous material to the ocean.

These conclusions are based on the following observations:

1) The amount of "desert quartz" (Radcewski, 1937) is generally high in the actual input and during interglacial periods, and low in glacial periods (DiesterHaass, 1976a, fig. 8). There are regional differences in the Holocene (desert quartz numbers varying between 300 at $27^{\circ} \mathrm{N}$ and 10 to 20 at $22^{\circ} \mathrm{N}$ ). However, the glacial values are rather constant, ranging between 20 and $<5$ during Oxygen Stages 2, 3, and 4 in the area between $27^{\circ}$ and $20^{\circ} \mathrm{N}$. Red-staining of quartz grains can occur in both arid (Walker, 1967) and in subtropical semi-humid regions. Furthermore, red-stained quartz occurs in the Sahara in Tertiary and lower Quaternary sediments. The numerical reduction of red-stained relative to colorless quartz during glacial periods points to destruction of their red hematite coating. This is fostered by more humid conditions and soil formation (McArthur and Bettenay, 1960) or during river transport (Walker, 1967, 1974; van Houten, 1964, 1972).

The following observations made on the investigated cores, led to the conclusion that the glacial climate was more humid than that of the Holocene and Eem time intervals: (a) the clay minerals indicate soil formation during increased wetness in glacial times (Chamley et al., 1977); (b) phytoliths are present which suggests more humid conditions (Schrader in Diester-Haass et al., 1973); (c) pollen reflect mediterranean vegetation during the last glacial in the actual desert areas (Agwu, 1975; Beug, Göttingen, personal communication).

The last glacial period is subdivided into Oxygen Stages 2, 3, and 4 which is clearly reflected in the $\mathrm{CaCO}_{3}$ and per cent terrigenous matter curves (higher carbonate values, less terrigenous input $>40 \mu \mathrm{m}$ in Stage 3 than in Stages 2 and 4). But desert quartz numbers consistently remain low. This suggests climatic variations which, however, where not strong enough to prevent the destruction of the red staining.

2) The grain size of terrigenous material $>40 \mu \mathrm{m}$ is another basis for concluding trends of climatic variations. In the recent sediment input and in the interglacial intervals, hardly any quartz in the $>63 \mu \mathrm{m}$ fraction and none in the $>125 \mu \mathrm{m}$ have been found; whereas, in glacial periods, during phases of highest terrigenous input (smallest $\mathrm{CaCO}_{3}$ values), quartz $>63$ $\mu \mathrm{m}$ and $>125 \mu \mathrm{m}$ is found in large amounts (i.e., up to $6 \%$ of sand-sized quartz is coarser than $125 \mu \mathrm{m}$ in Meteor Cores 12379 at $2000 \mathrm{~m}$ water depth and in $\mathrm{Me}$ teor Core 12310 at $3000 \mathrm{~m}$ water depth; Diester-Haass et al., 1973). After Bagnold (1954) and based on find- 
ings from recent dust storms, no quartz $>80 \mu \mathrm{m}$ can be transported in suspension by the wind. Particles up to $200 \mu \mathrm{m}$ diameter are mostly aggregates formed by rain drops (Jänicke, personal communication 1977). The climate off Senegal during Stage 2 was arid with dunes migrating over the shelf (Sarnthein and Diester-Haass, 1978b; Diester-Haass, 1975). The sediments on the continental slope consist of Eolian quartz with high amounts of stained quartz. But only 0 to 0.5 per cent of the sand-sized quartz is coarser than $125 \mu \mathrm{m}$, compared to 5 per cent in the same setting and at an even greater distance from the coast off the northern Sahara. This favors Bagnold's (1954) data, by indicating that even strong winds do not transport important quantities of quartz $>80 \mu \mathrm{m}$.

The findings described in the first point, desert quartzes, and these grain-size data lead to the interpretation of river input during the last glacial period, which is in good agreement with land data (see Rognon and Williams, 1977).

This climatic interpretation is partly of varience to that presented by Lutze et al. (this volume). Sarnthein, (1978) found in land data an arid period of about 2000 years duration in the northern Sahara (from 20,000 to 17,800 B.P.). Before and after this arid interval, the climate had been wetter, which corresponds to the interpretation in the study. During the entire last glacial period (Stages 2, 3, and 4), sedimentological conditions are not found to vary strongly in all the Meteor cores studied off the Sahara, but do vary stongly compared to the interglacials (Stages 1 and 5). These results preclude the conclusion that the coarse quartz $(>150 \mu \mathrm{m})$ peak in Stage 2 of Core 12309 is the result of arid conditions and eolian input (Lutze et al., this volume).

The arid period lasted only 2000 years, and is a short interval during a long-lasting wet period. This wet period determined the sedimentological parameters in the marine environment, whereas the short arid period during peak-glacial conditions is not clearly reflected in the marine record.

The same holds true for the Holocene period: the actual indicators of terrigenous input from the Sahara (no quartz $>125 \mu \mathrm{m}$, almost no quartz in the 63 to $125 \mu \mathrm{m}$ fraction, and high numbers of stained quartz), an arid region today, remained the same during the entire Holocene. One slight difference can be observed: the amount of terrigenous matter in the 40 to $63 \mu \mathrm{m}$ fraction was lower in the early Holocene than at present, this can be observed all along the Africa continental margin between $20^{\circ} \mathrm{N}$ and Portugal (Kudrass, 1973). The relatively constant (qualitatively and quantitatively) Holocene terrigenous input does not reflect the short-term climatic changes which have been observed on the continent (Lutze et al., this volume).

Closer sampling and more precise grain-size data might allow the reconstruction of a more detailed African climatic history from the marine sediments.

Applying these results to the sediments of Site 397, one obtains the following climatic divisions:

1) Quaternary, with numerous changes between arid and humid climate.

2) Pliocene, mainly arid.
3) Late Miocene, with some changes between humid and arid climate.

In the upper part of the Quaternary, Cores 2 to 11 , there are numerous changes between strong terrigenous input in the coarse fraction, which are coincident with low desert quartz numbers. These are interpreted as periods of humid climate with abundant rainfall and river sediment supply. Then there are layers with nearly no terrigenous material in the $>63 \mu \mathrm{m}$ fraction, and $<5$ to 10 per cent in the 40 to $63 \mu \mathrm{m}$ fraction; desert quartz numbers are above 20 in this interval (Figure 3 ). These layers are interpreted as being deposited during an arid climate with mainly an eolian supply. In the late Quaternary sediments from Meteor Core 12309, taken near Site 397, the variations are of the same order of magnitude (Chamley et al., 1977). Some disagreement between amount of terrigenous material and desert quartz numbers in Meteor Core 12309 (explained by its location close to the climatic boundary between Mediterranean humid and Saharan arid climate; Chamley et al., 1977) could not be found in the Quaternary at Site 397, except for the uppermost samples. This might also be due to drilling distrubances. In Cores $397-2$ to 11 , five or six humid climate sediment intervals can be distinguished. It would be interesting to know whether they can be correlated to the glacial cold periods described by Ruddiman (1971) and McIntyre and Jantzen (1969) for the Atlantic, or to the glacial periods on the continents, e.g., Cooke (1973). But the distance between samples is too great. It is not known whether the number of variations would increase with a smaller sample spacing.

In the lower Quaternary, in Cores 12 to 15 , there is only one humid phase (Sections 13-4 and 5) in a more stable arid climate period. Needham et al. (1969) also describe a quieter climatic background during the early Pleistocene compared to the late Pleistocene, at $8^{\circ} \mathrm{N}$ in the Atlantic Ocean. Perhaps this climatic evolution can be correlated to a major cooling and initiation of intense high latitude glaciation at about 0.6 to $0.4 \mathrm{~m}$.y. B.P. in the Arctic (Berggren and Hollister, 1974). Herman (1974) also found more constant conditions in the Arctic Sea prior to 0.7 m.y. B. P. and several rapid changes between 0.7 m.y. and the present. The temperature curves of Ruddiman (1971) and McIntyre and Jantzen (1969) for the Atlantic Ocean showed warmer and more stable conditions in the early Pleistocene prior to 0.7 m.y. These observations correlate well with the more stable arid climate in northwestern Africa, in the early Pleistocene.

Based on interpretations of the Quaternary section, high desert quartz numbers in the Pliocene section point to an arid climate. The amount of terrigenous material in the $>40 \mu \mathrm{m}$ fraction is low, compared to that in the Quaternary and points to a weak erosion of the continent and/or small wind velocities. The variations in amount of terrigenous material might be due either to variations in wind strength or to lateral supply of quartz grains from shallow water (cf. Chamley et al., this volume).

In the late Quaternary, south of $20^{\circ} \mathrm{N}$ off northwestern Africa, it has been found that during arid glacial 

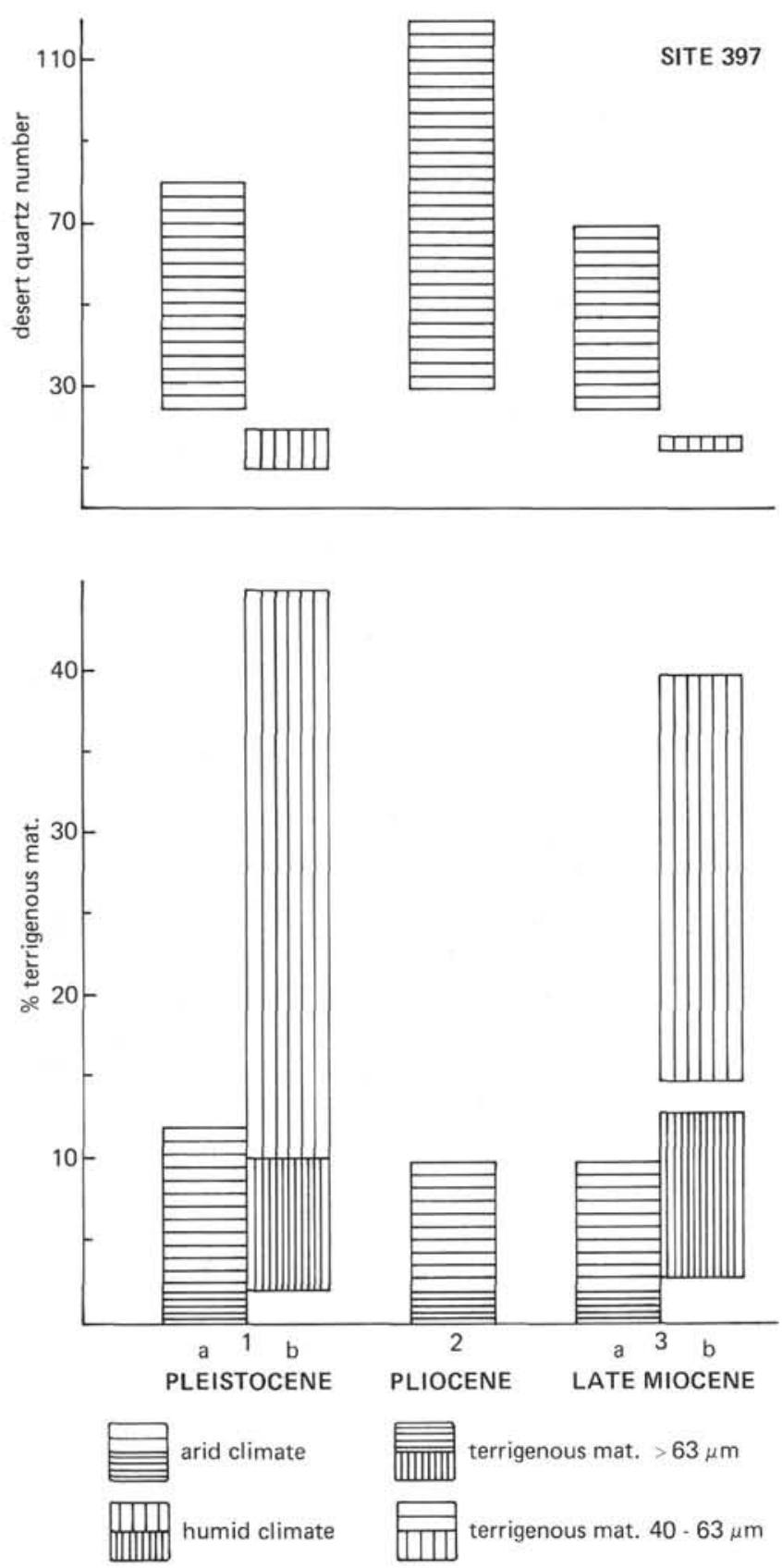

Figure 3. Amount of terrigenous material in the 40 to 63 and $>63 \mu \mathrm{m}$ fractions and desert quartz numbers in the 40 to $63 \mu \mathrm{m}$ fraction. Length of column gives width of variation. (1) Quaternary: (a) arid; (b) humid climate; (2) Pliocene arid climate; (3) Miocene: (a) arid, (b) humid climate.

periods wind strength increased sufficiently to produce an increase in eolian input by a factor of about two (Diester-Haass, 1976b). This explanation may apply to those layers where terrigenous input increases in the 40 to $64 \mu \mathrm{m}$ fraction, but not significantly in the $>63 \mu \mathrm{m}$ fraction, and where desert quartz numbers remain high (e.g., Core 17, Section 26-6, Core 28, Section 30-5 and $31-2$, etc.). There is, however, one sample in the Pliocene (Section 19-3), where terrigenous input in the 40 to $63 \mu \mathrm{m}$ fraction as well as in the 63 to $125 \mu \mathrm{m}$ fraction increases and where desert quartz numbers decrease to $<20$. This may represent a period with river supply caused by increased rainfall. The possibility of lateral supply from shallow water, however, should be taken into account, with reworking of older strata which contain no desert quartz. Textural studies could resolve this.

Desert quartz numbers are significantly higher during the Pliocene than during the Quaternary (Figure 3 ), pointing either to a stronger desert influence and staining of more grains, or to less dilution by non-desert (coastal?) grains.

In the upper Miocene sediments, there are alternations between layers with small terrigenous input and high desert quartz numbers, and layers with high terrigenous supply and low desert quartz numbers. When applying the results from the Quaternary sediments, this can be interpreted as being caused by a change between arid and humid climate (i.e., between mainly eolian and mainly fluvial supply). Arid periods are longer than humid ones in the late Miocene, whereas in the Quaternary they are of nearly equal length. The results from cores of proximal Site 369 (Diester-Haass, 1978a) favor this explanation. At Site 369, the late Miocene exhibited the same change in terrigenous input and desert quartz numbers, the absolute values being comparable. The succession of changes at both sites is similar. In the early late Miocene (Figure 4), there are numerous changes (Cores 397-52 to 397-56, 369-4 and 3695 , and $369 \mathrm{~A}-1$, and $369 \mathrm{~A}-2$ ), followed by a period with constant arid climate (Cores $397-47$ to $397-49$, and 396-3). Also, some changes occur just below the Miocene/Pliocene boundary (cf. Chamley and DiesterHaass, this volume).

Variations in amounts of terrigenous material cannot be explained entirely by dissolution and, thus, by enrichment of the noncarbonate particles, because the fragmentation curve and the curve showing amount of terrigenous material vary independently.

There are two problems in the climatic interpretation of the upper Miocene sequence. First, there are the three layers with benthic/planktonic ratios ranging to 25 per cent. They cannot be explained by dissolution or production changes. Only lateral supply is a possible explanation. Perhaps, down-slope transport is a possibility, as demonstrated for middle and lower Miocene strata; or, quartz grains may have come downslope from shallow water. It is conceivable that the redstained quartz from desert environment are diluted by reworked, older, non-stained quartz grains, thereby producing changes in terrigenous supply, grain size, and desert quartz numbers without any changes in climate on the continent.

The second problem is that the environment during that period (e.g , distance from the coast, bottom and surface currents, etc.) are not known. So it is not clear whether the actualistic model of either river or eolian supply can be applied without taking into account other origins of the terrigenous components. Tectonically induced more active erosion and the influence of folding and uplifting of the Atlas (Dillon and Sougy, 


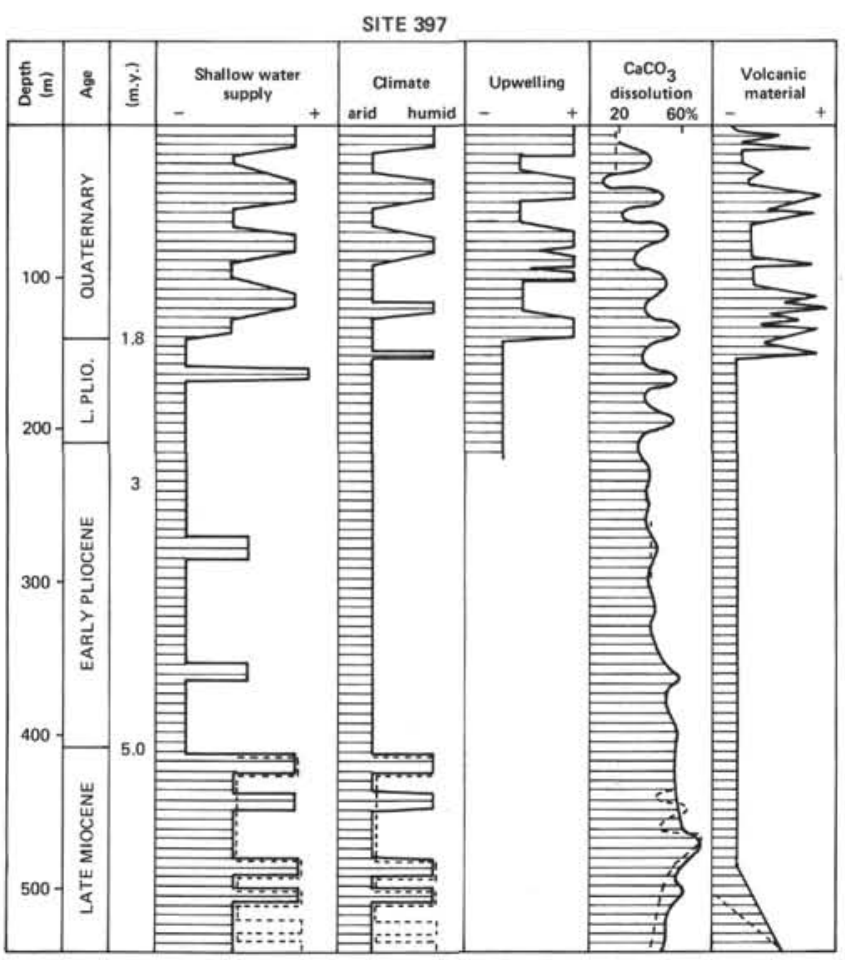

Figure 4. Schematic diagram showing results of coarse fraction analysis. Black line: results of Site 397; dotted line: tentative correlation with results of Site 369, Leg 41 (Diester-Haass, 1978a). The number of peaks in shallow water supply, climate, and upwelling are schematic. In the original diagrams, there were more peaks, which could not all be shown here. $\mathrm{CaCO}_{3}$ dissolution per cent values give amount of fragments of planktonic foraminifers in per cent of total planktonic foraminifer.

1974: main folding of the Atlas in the Miocene) might also be important.

There are two facts which allow the application of the actualistic model: (1) the good agreement between Sites 369 and 397, and (2) the good agreement between results from coarse-fraction analysis and clay minerals (Chamley and Diester-Haass, this volume).

The Antarctic ice-sheet had at the beginning of the late Miocene for the first time a larger extent (Shackleton and Kennett, 1975a). Perhaps there is some connection between this phenomenon and the climatic variations in northwestern Africa. The middle and early Miocene off northwestern Africa at Site 369 had an arid climate without humid intervals, based on the coarse terrigenous fraction data (Diester-Haass, 1978a).

A good visual correlation exists between this climatic interpretation for northwestern Africa and the oxygen isotope curve by Shackleton (Cita and Shackleton, this volume). In Cores 2 through $10, \delta^{18} \mathrm{O}$ variations are great, as are climatic changes. Peaks with small $\delta^{18} \mathrm{O}$ correlate with arid periods, and high $\delta^{18} \mathrm{O}$ values correlate with humid periods. In Cores 11 through 15 (lower Pleistocene), $\delta^{18} \mathrm{O}$ values are smaller and more uniform, as is appropriate for a generally arid climate. The only humid period in Core 13 is clearly reflected by higher $\delta^{18} \mathrm{O}$ values. The Pliocene, like the lower Pleistocene, has low and rather constant $\delta^{18} \mathrm{O}$ values, increasing in Core 19 , where a humid inter$\mathrm{val}$ is presumed. Stronger $\delta^{18} \mathrm{O}$ variations occur again in the upper Miocene, correlating well with the climatic interpretation: high $\delta^{18} \mathrm{O}$ values corresponding to humid phases, low values to arid periods.

The cold-warm classification, established by Lutze (this volume), based on benthic foraminifers, also correlates well with the Quaternary climatic interpretation presented here. Lutze's cold intervals correspond in general to humid periods, his warm intervals to an arid climate. His cold intervals, especially in Cores 3, 4, 5, and 8 , correspond to humid periods. Also the lower Pleistocene humid interval in Core 13 is clearly reflected as a cold stage by benthic foraminifers.

\section{Upwelling}

Several indicators for increased fertility in continental slope sediments off northwestern Africa have been described (Diester-Haass, 1978b). These indicators include the following, (1) high opal content in the total sediment; (2) increased numbers of diatoms, radiolarians, and sponges in the coarse fraction; (3) increased production of benthic foraminifers and, thus, benthic/ planktonic values which are higher than normal for the water depth; and (4) cold water assemblages of planktonic foraminifers. In very strong upwelling regions, phosphorite occurs and fish debris is enriched (DiesterHaass and Schrader, in press). Benthos may be completely absent in upwelling areas where bottom oxygen is absent.

The increased opal content is a "conditio sine qua non" for upwelling-influenced sediments. In normal fertile continental slope sediments, opal is usually completely dissolved by silica reconstitution reactions (Johnson, 1974, 1975). When opal input increases (mainly by diatoms, also by radiolarians), however, pore water will be saturated and allow the preservation of opal (Diester-Haass, 1978b).

Opal-bearing sediments at Site 397 are found in Cores 2 through 26. In Cores 27 to 56, no opal was found in fractions $>40 \mu \mathrm{m}$. The opal-containing sediments are interpreted as being due to upwelling, because opal can only be preserved when diatom production is high, and because nearly each radiolarian peak correlates to an increase in benthic/planktonic ratios of foraminifers. It is presumed that due to increased fertility in surface waters, food supply to the bottom increased allowing a higher benthic foraminifer production. Upwelling, however, did not produce a reducing environment at the sediment/water interface, thereby excluding benthic life and allowing excellent $\mathrm{CaCO}_{3}$ preservation.

Several of the radiolarian peaks coincide with increases in echinoderms. It is possible that the increased food supply also enhanced echinoderm production. Some of the maximum values for ostracodes also coincide with opal and echinoderm and benthic foraminifer-rich samples. The layers with the highest opal con- 
tent, however, do not have increased ostracode values, but have the highest echinoderm amounts. Fish debris are not enriched in these upwelling-influenced sediments at Site 397. The same observation was made for upper Pleistocene sediments from the same area (Diester-Haass, 1977a). Phosphorite grains occur in small amounts (see Table 1), but it is highly possible that they are reworked (von Rad et al., in press; Tooms et al., 1971). Phosphorite is also absent in upper Quaternary, upwelling-influenced sediments off northwest Africa.

The interpretation of strong upwelling influence is reinforced in Section $10-3$ by a high organic carbon value $(2.38 \%$ ), proving high organic production (see Site Report, this volume). Highest pyrite amounts do not correlate with intervals of highest fertility.

The upwelling-influenced, opal-rich sediments are found mostly in intervals which point to a humid climate on the continent. The three layers with by far the highest opal content, highest benthic/planktonic ratios, and highest fertility (Sections 9-2, 10-3, and 15-1), however, are in sediments indicative of an arid climate.

There were probably two different circulation patterns responsible for the upwelling observed at Site 397. First, during humid (i.e., glacial) periods, sea-level was lowered and the circulation system was more energetic (Climap, 1976; Gates, 1976). This produced upwelling in areas, whereas no upwelling effect could be detected in the sediments during interglacial periods. The second model of upwelling, during arid periods, could be explained either by stronger trade winds, and/or a stronger Canary Current, or by changes in sea-floor morphology, or by a longer yearly span of upwelling. Actually, there is some present-day upwelling in the area of Site 397 , but only during the summer months. This upwelling is insufficient to influence the underlying sediments. In the center of the Trade Wind belt, off Cape Blanc at about $21^{\circ} \mathrm{N}$, however, there is strong upwelling and high primary production throughout the year (Schemainda et al., 1975). That is why sediments there, deposited during arid climatic phases (Holocene and Eem), reveal a strong upwelling influence (Diester)Haass, 1978b).

The general trend of upwelling influence at Site 397 is high in the upper Quaternary section (Cores 2 to $10)$, corresponding to the sequence with numerous climatic changes. During the lower Quaternary (Cores 11 to 15) and in the upper Pliocene, reflecting a climate that was more uniformly arid, the upwelling influence decreases. The beginning of the increased fertility at about Core 25 perhaps can be linked to the beginning of Arctic glaciation and, thus, to altered circulation patterns in the North Atlantic (Berggren, 1972), with several periods of stronger current and wind velocities.

During the late Miocene, climatic changes between humid and arid phases are probable, similar to those in the Quaternary. No upwelling influence, however, was found at Sites 397 and 369 (Diester-Haass and Schrader, in press). Perhaps the global climatic differences were still less extreme than during the Quaternary, producing weaker currents, especially a less well-developed
Canary Current and lower trade wind velocities. Von Rad et al. (in press), however, found indications of upwelling in the middle Miocene on the uppermost slope.

\section{Calcium Carbonate Dissolution}

The degree of fragmentation of planktonic foraminifers is believed to indicate the degree of $\mathrm{CaCO}_{3}$ dissolution. Five cycles were observed in the Quaternary sequence, and three cycles with increasing fragmentation were observed in the upper Pliocene (Cores 20, 22 to 23 , and 25 to 26 ). These cycles are not clearly relatable to climatic changes; they may be caused by pulses of deep cold North Atlantic water influx. Arctic glaciation began about 3 m.y. B.P., which corresponds to Cores 25 . Antarctic bottom water may have influenced dissolution as well. During the late Quaternary glacial periods, it strongly increased carbonate dissolution in the equatorial Atlantic (Western part: Damuth, 1975; Eastern part: Gardner, 1975; Diester-Haass et al., 1978). Strong bottom water formation probably increased in Antarctica at about 3.75 m.y. B.P. (Blank and Margolis, 1975), 3.3 to 2.4 m.y. B.P. (Watkins and Kennett, 1971), during the onset of Antarctic ice shelf formation. The bottom water traveled farther north during glacial periods than during interglacials (Burckle and Stanton, 1975).

At about 2.5 m.y. B.P., erosion off Antarctica increased strongly due to the formation of cold bottom water (Kennett and Watkins, 1976). Perhaps this bottom water temporarily shifted northwards and produced cycles with increasing carbonate dissolution in the North Atlantic, superimposed on a general decrease in $\mathrm{CaCO}_{3}$ dissolution.

Fragmentation varies without trend in Cores 25 to 34 , but there may have been cycles which could not be detected because of the large sample intervals. In the lower Pliocene (Core 37), dissolution begins to increase, with maximum values occurring in the upper Miocene (Core 52). In the lower upper Miocene, values decrease again. In the upper Miocene, there are strong variations (between 45 and $70 \%$ ). The upper Miocene trend in dissolution is similar to that at Site 369 (Diester-Haass, 1978a), with highest values in the middle upper Miocene and lower values in the upper and lower part of that period, and strong variations between very low and very high values. The lower Pliocene fragmentation is smaller than that of the Miocene, and the Quaternary dissolution is smaller than that of the Pliocene at Sites 369 and 397 . The same trend has been described for depth variations of the carbonate compensation depth in the North Atlantic (Berger and von Rad, 1972). Miocene fragmentation percentages of 45 to 70 per cent at Site 397 are similar to those at Site 369 , although the latter is situated in only 1800 meters water depth. The lowest Quaternary value at Site 369 is 20 per cent, the same as the lowest value at Site 397. This general correspondance in dissolution trends at the two sites (and also at Site 366) favors the interpretation of large-scale change in depth of the lysocline, and counters interpretaion of local reasons for dissolution changes (for discussion, see Diester-Haass, 1978a). 
Upper Quaternary fragmentation values in Meteor Cores 12309-1, taken from the same location as Site 397 , vary without trend between 15 and 30 per cent. These values correspond to the lowest Quaternary values found at Site 397.

It has been observed (Berger, 1970; Lisitzin, 1971, 1972; Moore et al., 1973) that with increasing fertility, $\mathrm{CaCO}_{3}$ dissolution increases. But when the $\mathrm{O}_{2}$ amount becomes too small and the reduction zone in the sediment is in contact with the bottom water, $\mathrm{CaCO}_{3}$ preservation can be excellent (Berger and Soutar, 1970; Stackelberg, 1972; Diester-Haass, 1978a).

There is no correlation between dissolution increases or decreases and changing fertility at Site 397 . There are two explanations for this lack of correlation. First, characteristics of bottom water, either arctic or antarctic, are more decisive for the degree of dissolution than local fertility changes. Second, fertility was never high enough to produce a reducing zone at the sediment/ water interface, as has already been demonstrated by the benthic/planktonic ratios of foraminifers.

\section{Volcanism}

The amount of volcanic material shows maximum values during the last 2 m.y. (Cores 2 to 16 ). This correlates with $\mathrm{K}-\mathrm{Ar}$ age determinations of volcanic samples from the Canary Islands, Tenerife, Palma, and Hierro (Abdel-Monem et al., 1972). The isle of Gran Canaria, however, situated closest to Site 397, had a main volcanic phase during 3.5 to 2 m.y.B.P. (Abdel-Monem et al., 1971; Grunau et al., 1975). Lietz and Schmincke (1975) found evidence for volcanic activity in the northeast half of Gran Canaria in the Quaternary until late prehistoric times. In the remaining sequences studied of Site 397, volcanic material is present in small amounts. Values increase only in the upper Miocene interval; this might correlate to the end of a volcanically active period spanning from 16 to 9 m.y. B.P. (cf. Schmincke et al., this volume).

The origin of the volcanic material found at Site 397 Cores 2 to 56 , can be related to eloian supply and submarine transport. Volcanic eruptions on the Canary Islands and eolian supply of the volcanic glass and ash may have produced the peaks in volcanic material in the upper Pliocene and Quaternary, and in the lower part of the upper Miocene. The volcanic material in the sections with low glass and ash quantities at Site 397 could have been supplied from shallow water by submarine transport processes. Lietz and Schmincke (1975) report that canyons are partly filled with volcanic material and that sedimentary rocks interfinger with volcanic clastic debris fans. The constant presence of small amounts of volcanic material which cannot be correlated to volcanic phases, perhaps justifies the conclusion that this material came from the continental shelf or slope off the Canary Islands. This assertion is favored by the following observation: the Neogene section at Site 369 (situated southeast of Site 397, in shallower water on the African continental slope) contained volcanic material only in two well-defined layers which can be correlated with volcanic phases on the Canary Islands (Diester-Haas, 1978a). This observa- tion indicates that perhaps Site 369 only received volcanic material by eolian transport from eruptions, whereas Site 397 (closer to these islands, but in deeper water) received volcanic material both from eruptions and by bottom transport from the Canary Island continental slope.

It cannot be deduced whether the biogenous shallow water particles and the glauconite and relict material accompanied the volcanic material from the Canary Island slope, or originated from the steep African continental slope, or from both areas. Clay minerals, however (Chamley, this volume), do not indicate a Canary Island influence.

\section{ACKNOWLEDGMENTS}

I thank the scientific crew of IPOD Leg 47A, especially B. Ryan, U. von Rad, G. Lutze, and M. Sarnthein for providing samples for shore-based analysis. Thanks are due to M. Arthur, H. Chamley, U. von Rad, and E. Seibold for helpful comments on the manuscript.

I would like to express my sincere thanks to W. Schnitzer for providing working facilities. Thanks are due to B. Alberts, A. Rongitsch, and R. Schneider for careful sample preparation. The financial support of the Deutsche Forschungsgemeinschaft is gratefully acknowledged.

\section{REFERENCES}

Abdel-Monem, A., Watkins, N. D. and Gast, P. W., 1971. Potassium argon ages, volcanic stratigraphy and geomagnetic polarity history of the Canary Islands: Lanzarote, Fuerteventura, Gran Canaria, and LaGomera, Am. J. Science, v. 271, p. 490-521.

1972. Pottassium argon ages, volcanic stratigraphy, and geomagnetic polarity history of the Canary Islands: Tenerife, La Palma, and Hierro, Am. J. Science, v. 272 , p. $805-825$.

Agwu, C., 1976. Vegetations-und klimageschichtliche Untersuchungen an marinen Sedimenten von der west-afrikanischen Kuste. Methodische Grundlagen. Dipl-Arbeit, Göttingen, 1975.

Arrhenius, G., 1952. Sediment cores from the East Pacific, Rept. Swedish Deep-Sea Exped., v. 5.

Bagnold, R. A., 1954. The physics of blown sand and desert dunes: London (Methuen and Co.).

Berger, W. H., 1970. Planktonic foraminifera: selective solution and the lysocline, Mar. Geol., v. 8, p. 111-138.

Berger, W. H. and Soutar, A., 1970. Preservation of plankton shells in an anaerobic basin off California, Geol. Soc. Am. Bull., v. 81 , p. $275-282$.

Berger, W. H. and von Rad, U., 1972. Cretaceous and Cenozoic sediments from the Atlantic Ocean. In Hayes, D. E. and Pimm, A. C. et al., Initial Reports of the Deep Sea Drilling Project, v. 14: Washington (U.S. Government Printing Office), p. 787-954.

Berggren, W. A., 1972. Late Pliocene-Pleistocene glaciation. In Laughton, A. S. Berggren, W. A., et al., Initial Reports of the Deep Sea Drilling Project, v. 12: Washington (U.S. Government Printing Office), p. 953-963.

Berggren, W. A. and Hollister, C. D., 1974. Paleogeography, paleobiogeography and the history of circulation in the Atlantic Ocean. In Hay, W. W. (Ed.), Studies in paleooceanography. Soc. Econ. Pal. and Min., Spec. Publ. 20, p. 126-186.

Blank, R. G. and Margolis, S. V., 1975. Pliocene climatic and glacial history of Antarctica, as revealed by south-east Indian Ocean deep-sea cores, Geol. Soc. Am. Bull., v. 86, p. 1058-1066. 
Burckle, L. H. and Stanton, D., 1975. Distribution of displaced Antarctic diatoms in the Argentine Basin, Nova Hedwigia, v. 53, p. 283-292.

Chamley, H., Diester-Haass, L., and Lange, H., 1977. Terrigenous material in East Atlantic sediment cores as an indicator of NW African climates, Meteor Forsch.-Ergebn., Reihe C., v. 26, p. 44-59.

Climap Project Member, 1976. The surface of the ice-age earth, Science, v. 191, p. 1131-1144.

Cooke, H. B. S., 1973. Pleistocene chronology: long or short?, Quat. Res., v. 3, p. 206-220.

Damuth, J. E., 1975. Quaternary climate change as revealed by calcium carbonate fluctuations in western Equatorial Atlantic sediments, Deep-Sea Res., v. 22, p. 725-743.

Diester-Haass, L., 1975a. Sedimentation and climate in the late Quaternary between Senegal and the Cape Verde Islands, Meteor Forsch. Ergebn., Reihe C., v. 20, p. 1-32. $1975 \mathrm{~b}$. Influence of deep-oceanic currents on calcareous sands off Brazil, IXiem Congrés International de Sédimentologie, Nice, 1975, p. 25-30.

1976a. Late Quaternary climatic variations in Northwest Africa deduced from East Atlantic sediment cores, Quat. Res., v. 6, p. 299-324.

1976b. Quaternary accumulation rates of biogenous and terrigenous components on the East Atlantic continental slope of NW Africa, Mar. Geol., v. 21, p. 1-24. 1977. Radiolarian/planktonic foraminiferal ratios in a coastal upwelling region, J. Foram. Res., v. 7, no. 1, p. 26-33.

1978a. Influence of carbonate dissolution, climate, sea-level changes and volcanism on Neogene sediments off NW-Africa (Leg 41). In Lancelot, Y., Siebold, E., et al., Initial Reports of the Deep Sea Drilling Project, v. 41: Washington (U.S. Government Printing Office), p. 1033-1047.

$1978 \mathrm{~b}$. Sediments as an indicator of upwelling. In Proceedings of the Third International Symposium on Upwelling Ecosystems: Kiel (Springer Verlag), p. 261-281.

Diester-Haass, L. and Schrader, H.-J., in press. Neogene coastal upwelling history off NW and SW Africa, Mar. Geol.

Diester-Haass, L., Schrader, H.-J., and Thiede, J., 1973. Sedimentological and paleoclimatological investigations of two pelagic ooze cores off Cape Barbas, NW Africa, Meteor Forsch. Ergebns. Reihe C., v. 16, p. 19-66.

Diester-Haass, L., Kögler, C.-F., and Seibold, E., 1978. Site 367-Appendix A: Geological problems of the uppermost 8 meters. In Lancelot, Y., Seibold, E., et al., Initial Reports of the Deep Sea Drilling Project, v. 41: Washington (U.S. Government Printing Office), p. 189-192.

Dillon, W. P. and Sougy, J. M. A., 1974. Geology of West Africa and Canary and Cape Verde Islands. In Nairn, E. M. and Stehli, F. C. (Eds.), The ocean basins and margins. v. 2, The North Atlantic: New York, London (Plenum Press), p. 315-390.

Embley, R. W., 1976. New evidence for occurrence of debris flow deposits in the deep sea, Geology, v. 4, p. 371-374.

Gardner, J. V., 1975. Late Pleistocene carbonate dissolution cycles in the Eastern equatorial Atlantic. In Dissolution of deep sea carbonates. Spec. Publ. No. 13. (Cushman Foundation for Foraminiferal Research), p. 129-141.

Gates, W. L., 1976. Modeling the ice-age climate, Science, v. 191 , p. 1131-1144.

Grunau, H. R., Lehner, P., Cleintuar, M. R., Allenbach, P. and Bakker, G., 1975. New radiometric ages and seismic data from Fuerteventura (Canary Islands), Maio (Cape Verde Islands), and Sao Tomé (Gulf of Guinea). In Progress in Geodynamics: Amsterdam (Royal Netherlands Acad. of Arts and Sciences).
Herman, Y., 1974. Arctic ocean sediments, microfauna and the climatic record in late Cenozoic time. In Herman, Y. (Ed.), Marine geology and oceanography of the Arctic Seas: New York (Springer Verlag), p. 283-348.

Johnson, T. C., 1974. The dissolution of siliceous microfossils in surface sediments of the eastern tropical Pacific, DeepSea Res., v. 21, p. 851-864.

1975. The dissolution of siliceous microfossils in deep-sea sediments, $\mathrm{PhD}$ thesis, University of California, San Diego.

Kennett, J. P. and Watkins, N. D., 1976. Regional deep-sea dynamic processes recorded by late Cenozoic sediments of the southeastern Indian Ocean, Geol. Soc. Am. Bull., v. 87, p. 321-339.

Kudrass, H. R., 1973. Sedimentation am Kontinentalhang vor Portugal und Marokko im Spätpleistozän und Holozän, Meteor Forsch. Ergebn. C, v. 13, p. 1-63.

Lietz, J. and Schmincke, H. U., 1975. Miocene-Pliocene sealevel changes and volcanic phases on Gran Canaira ( $\mathrm{Ca}-$ nary Islands) in the light of new K-Ar ages, Paleogeogr., Paleoclimat., Paleoecol., v. 18, p. 213-239.

Lisitzin, A. P., 1971. Distribution of siliceous microfossils in suspension and in bottom sediments. In Funnell, B. M. and Riedel, W. R. (Eds.), Micropaleontology of oceans: London (Cambridge Univ. Press), p. 173-195. 1972. Sedimentation in the world ocean, Soc. Econ. Pal. and Min., Spec. Publ., v. 17.

McArthur, W. M. and Bettenay, E., 1960. The development and distribution of the soils of the San River coastal plain, West. Australia.-Soil Publ. 16, Australia (CSJRO).

McIntyre, A. and Jantzen, R., 1969. Paleogeography and stratigraphy of coccolith carbonate in the Pleistocene North Atlantic, 7th Cong. Inqua, Résumés des Communications, Sec. II, v. 68 .

Moore, T. C., Heath, R. G., and Kowsman, R. O., 1973. Biogenic sediments of the Panama Basin, J. Geol., v. 81, p. 458-472.

Needham, H. D., Conolly, J. R., Ruddiman, W. F., Bowles, F. A., and Heezen, B. C., 1969. Continental sediment in equatorial Atlantic ooze: a climatic record of the Pleistocene, Geol. Soc. Am., Annual Meeting, Abstract, Part 7, p. 158-159.

Norris, R. M., 1969. Dune reddening and time, J. Sediment Petrol, v. 39, p. 7-11.

Radcewski, O. E., 1937. Die Mineralfazies der Sedimente des Kapverdischen Beckens, Wiss. Ergebn. Dt. Atlant. Exped. "Meteor" 1925-1927, Bd. III, v. 3, p. 262-277.

Rognon, P. and Williams, M. A. J., 1977. Late Quaternary climatic changes in Australia and North Africa: A preliminary interpretation, Paleogeogr., Paleoclimat., Paleoecol., v. 21 , p. $285-327$.

Ruddiman, W. F., 1971. Pleistocene sedimentation in the equatorial Atlantic: stratigraphie and faunal paleoclimatology, Geol. Soc. Am. Bull., v. 82, p. 283-302.

Sarnthein, M., 1978. Sand deserts of peak glacial and interglacial times, Nature, v. 272 , p. $43-46$.

Sarnthein, M. and Diester-Haass, L., 1977. Eolian sand turbidites, J. Sediment. Petrol., v. 47, p. 868-890.

Schemainda, R., Nehring, D., Schulz, S., 1975. Ozeanologische Undersuchungen zum Produktionspotential der nordwestafrikanischen Wasserauftriebsregion 1970-1973, Geod. Geophys. Veroff., R. IV, H. 16, Berlin.

Schlanger, S. O. and Douglas, R. G., 1974. Pelagic oozechalk-limestone transition and its implications for marine stratigraphy. In Hsü, K. J. and Jenkins, H. C. (Eds.), Pelagic sediments on land and under the sea: (International Assoc. Sediment.), Spec. Publ. No. 1, p. 117-148. 
Shackleton, N. J. and Kennett, J. P., 1975a. Paleotemperature history of the Cenozoic and the initiation of Antarctic glaciation: oxygen and carbon isotope analysis in DSDP Sites 277, 279 and 281. In Kennett, J. P., Houtz, R. E., et al., Initial Reports of the Deep Sea Drilling Project, v. 29: Washington (U.S. Government Printing Office), p. 743-755.

1975b. Late Cenozoic oxygen and carbonate isotopic changes of the northern hemisphere and Antarctica. In Kennett, J. P., Houtz, R. E., et al., Initial Reports of the Deep Sea Drilling Project, v. 29: Washington (U.S. Government Printing Office), p. 801-807.

Stackelberg, U. von, 1970. Faziesverteilung in Sedimenten des indisch-pakistanischen Kontinentalrandes (Arabisches Meer), Meteor Forsch.-Ergebn. Reihe C., v. 9, p. 1-73.

Tooms, J. S., Summerhayes, C. P., and McMaster, R., 1971. Marin geological studies on the north-west African margin. Rabat-Dakar-. ICSU/SCOR Working Party 31, Symp. Cambridge, 1970, Inst. of Geol. Sci. Rept. No. 70/ 16 , p. $9-25$.

van Houten, F. B., 1964. Origin of red beds-some unsolved problems. In Nairn, A. E. M. (Ed.), Problems in paleoclimatology, p. 647-659.

1972. Iron and clay in tropical savanna alluvium, northern Columbia: a contribution to the origin of red beds, Geol. Soc. Am. Bull., v. 83, p. 2761-2772.

von Rad, U., Čepek P., Stackelberg, U. von, Wissmann, G., and Zobel, B., in press. Cretaceous and Tertiary carbonate rocks from the lower continental slope off West-Sahara (Africa), Mar. Geol.

Walker, T. R., 1967. Color of recent sediments in tropical Mexico: a contribution to the origin of red beds, Geol. Soc. Am. Bull., v. 78, p. 917-920.

1968. Formation of red beds in modern and ancient deserts, Geol. Soc. Am. Bull., v. 78, p. 353-368.

, 1974. Formation of red beds in moist tropical climates: a hypothesis, Geol. Soc. Am. Bull., v. 85, p. 633638 .

Watkins, N. D. and Kennett, J. P., 1971. Antarctic bottom water: major change in velocity during the Late Cenozoic between Australia and Antarctica, Science, v. 173, p. 813818 .

\section{APPENDIX}

After completion of the manuscript, 12 more samples were taken from Sections 21-6, 22-5, and 23-3. The aim of this investigation was to determine if the layers with a supply of coarse terrigenous and shallow water material found at Samples $21-6,80 \mathrm{~cm} ; 22-5,80 \mathrm{~cm}$; and $23-3,80 \mathrm{~cm}$ were thin layers, produced by a sudden event (turbidite?).
Additional samples were taken in Samples 21-6, 65, 75, 85, and $95 \mathrm{~cm}$; Samples 22-5, 65, 75, 85, and $95 \mathrm{~cm}$; and Samples 23-3, 65, 75,85 , and $95 \mathrm{~cm}$ (see Table $\mathrm{i}$ and Figure i). The results from the 12 additional samples, taken within $30 \mathrm{~cm}$ of the previously investigated samples, do not differ very much from each other and from the previous samples.

The radiolarian/planktonic foraminiferal ratios, amounts of diatoms, and fish debris in the "coarser layers" are exactly in the same order of magnitude as those of the samples without coarse terrigenous and shallow water supply.

The main difference between "coarser layers" and surrounding sediments is the grain-size distribution (increase in sand and the 40 to $63 \mu \mathrm{m}$ fraction; Figure $5[\mathrm{a}])$, the drastic increase in per cent terrigenous material in the sand fraction (from 0 to $50 \%$; Figure i[c]), and the high content in glauconite, phosphorite, and relict material (Figures $5[\mathrm{~g}],[\mathrm{h}]$, and [i]), as well as a slight increase in benthic/planktonic ratios of foraminifers, in Sections 21-6 and 23-3 (Figure i[b]). Furthermore, quartz grains in the $>125 \mu \mathrm{m}$ fraction, absent in the "normal sediment," comprise up to 70 per cent of the total sand-sized quartz (Figure i[e]). Mica is nearly absent; $<0.5$ per cent in the sand fraction. The increase in terrigenous matter as well as in shallow water particles is higher in the sand than in the 40 to $64 \mu \mathrm{m}$ fraction. This phenomenon, together with the high median diameters (125 to $250 \mu \mathrm{m}$ ) of the quartz grains, shows that the main lateral supply is in the sand fraction.

Desert quartz numbers also reveal a stronger dilution of redstained quartz by white quartz in the sand than in the 40 to $63 \mu \mathrm{m}$ fraction. Normally, values are similar in both fractions. In the "coarser layers," however, smaller numbers of sand-sized quartz have red staining (Figure i[f]). The values in the 40 to $63 \mu \mathrm{m}$ fraction are rather high ( 30 to 60 ), pointing to an arid climate during deposition of the "coarser layers."

The samples taken in Sections 21-6, 22-5, and 23-3, all reveal an influence of a strong shallow water sediment supply. Thus, the "coarser layers" are thicker than $30 \mathrm{~cm}$, but thinner than $200 \mathrm{~cm}$. More samples have to be taken within this interval of Cores 21 to 23 , to establish the sequence and thickness of shallow water influenced sediments.

The origin of these layers remains unclear. The grain size of the quartz is too large to be explained by eolian supply (Bagnold, 1954). Also, rivers do not seem capable of transporting such quantities or coarse quartz grains (Diester-Haass, 1976a). Contourite currents or other bottom currents cannot account for the presence of shallow water particles. The large amounts of stained quartz, as well as the large median diameters of the quartz (125 to $250 \mu \mathrm{m})$, and the nearly complete absence of mica support interpretation of a desert climate and supply from sand dunes (Sarnthein and Diester-Haass, 1977). But the sediments can hardly be interpreted as "eolian sand turbidites"' (Sarnthein and Diester-Haass, 1977), because the size of the fine fraction $(<63 \mu \mathrm{m})$ is too high $(>85 \%)$. It is presumed that the shallow water particles and the dune sand were transported down slope by a mechanism other than normal hemipelagic sedimentation. It is not possible to tell whether sea level had been lower, thus facilitating down-slope transport by means of particle by particle transport. Alternatively, small turbidites, consisting mainly of dune

TABLE $\mathrm{i}$

Composition of the Sand Fraction From 12 Additional Samples, Taken Within "Coarse Layers" of the Upper Pliocene of Hole 397, Leg 47A

\begin{tabular}{|c|c|c|c|c|c|c|c|c|c|c|c|}
\hline $\begin{array}{l}\text { Sample No. } \\
\text { (Interval in } \mathrm{cm} \text { ) }\end{array}$ & Radiol. & Diat. & Pl. For. & Fish d. & Benthics & Relict m. & Phosph. & Glauc. & Volc. $m$. & Pyrite & Terrig. $\mathrm{m}$. \\
\hline $21-6,65-67$ & 5.84 & - & 60.67 & 0.17 & 5.07 & 2.11 & 0.41 & 0.12 & 5.09 & 1.74 & 18.70 \\
\hline $21-6,75-77$ & 6.92 & 0.38 & 62.70 & 0.06 & 5.26 & 0.77 & 0.45 & 0.22 & 2.59 & 4.09 & 16.53 \\
\hline $21-6,85-87$ & 4.40 & - & 42.81 & 0.27 & 4.90 & 5.10 & 0.75 & 0.24 & 11.47 & 1.62 & 28.44 \\
\hline $21-6,95-97$ & 6.07 & - & 59.64 & 0.06 & 5.94 & 0.76 & 0.15 & 0.08 & 15.16 & 8.05 & 4.02 \\
\hline $22-5,65-67$ & 1.82 & - & 72.02 & 0.30 & 2.12 & 1.38 & 1.65 & 0.37 & 7.91 & 3.60 & 8.83 \\
\hline $22-5,75-77$ & 2.06 & - & 65.21 & 0.27 & 1.01 & 3.67 & 1.62 & 0.53 & 11.88 & 3.14 & 10.31 \\
\hline $22-5,85-87$ & 1.38 & 0.04 & 63.98 & 0.16 & 2.30 & 4.11 & 1.74 & 0.58 & 3.03 & 5.18 & 17.48 \\
\hline $22-5,95-97$ & 1.85 & 0.04 & 59.08 & 0.05 & 1.66 & 4.54 & 1.00 & 0.30 & 1.27 & 6.14 & 23.99 \\
\hline $23-3,65-67$ & 1.08 & - & 64.51 & 0.24 & 3.55 & 3.35 & 0.90 & 0.34 & 2.14 & 2.72 & 21.16 \\
\hline $23-3,75-77$ & 0.26 & - & 32.86 & 0.24 & 3.87 & 4.22 & 6.92 & 0.38 & 0.65 & 1.92 & 48.68 \\
\hline $23-3,85-87$ & 0.53 & - & 43.22 & 0.13 & 3.33 & 8.23 & 4.17 & 0.22 & 0.12 & 1.89 & 38.14 \\
\hline $23-3,95-97$ & 1.21 & 0.05 & 71.77 & 0.13 & 3.79 & 1.44 & 1.89 & 0.20 & 0.66 & 3.24 & 15.62 \\
\hline
\end{tabular}




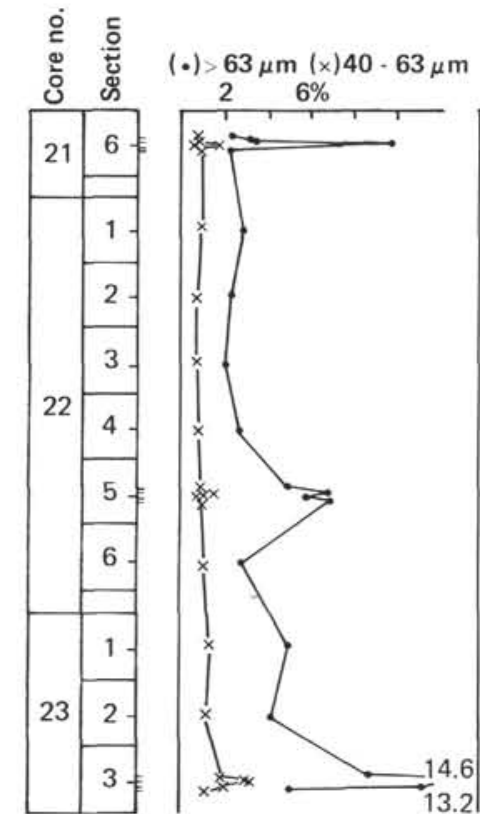

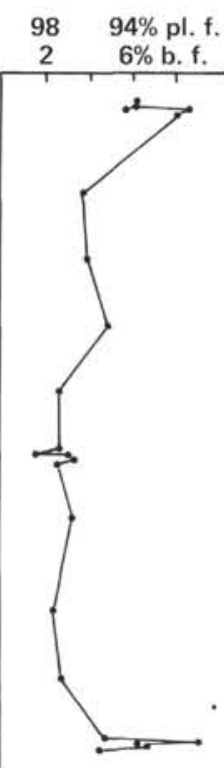

B

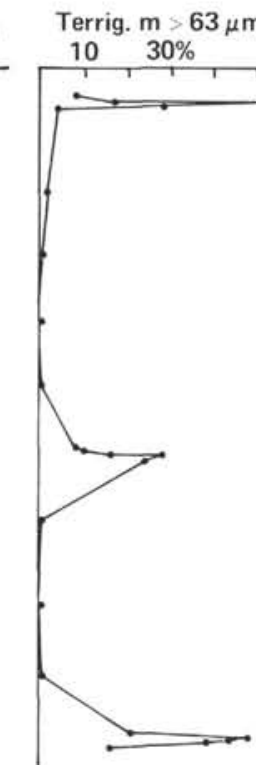

C

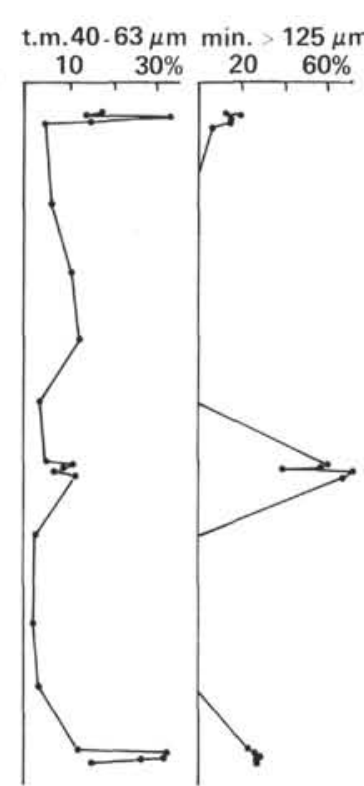

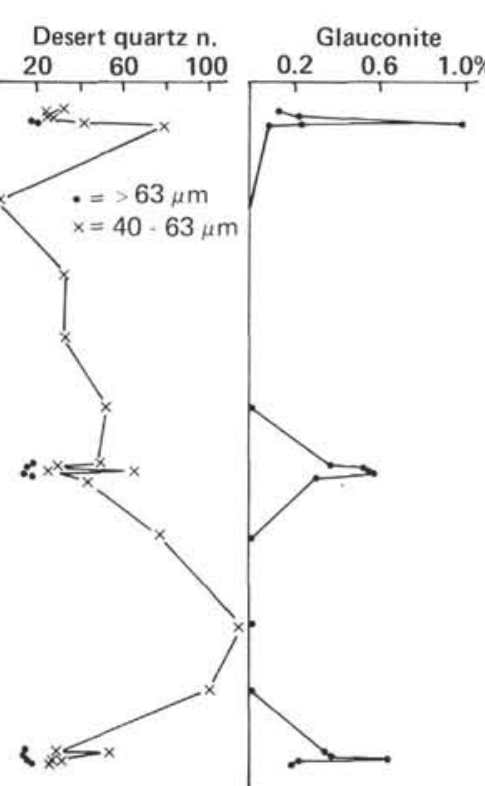

G
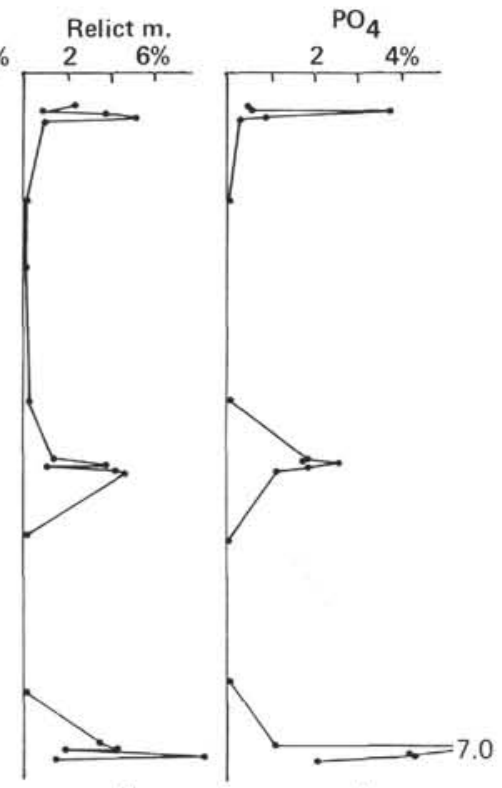

igure i. Results of coarse fraction analysis of additional samples in Cores 21, 22, and 23. (a) Per cent sand (>63 $\mu m$ ) and 40 to $63 \mu m$ fraction of total sediment (b) benthic/planktonic ratio of foraminifers, calculated as (b/b.+pl.) $\times 100 ;(c)$ per cent terrigenous material in the $>63 \mu m$ fraction; (d) per cent terrigenous material in the 40 to $63 \mu \mathrm{m}$ fraction; (e) per cent minerals (except mica) coarser than $125 \mu \mathrm{m}$ in per cent of total sand-sized minerals; ( $f$ ) desert quartz numbers, calculated as (red-stained quartz/colorless quartz) $\times 100 ;(\mathrm{g})$ per cent glauconite in the $>63 \mu \mathrm{m}$ fraction; (h) per cent relict material in the $>63 \mu \mathrm{m}$ fraction; $(i)$ per cent phosphorite grains in the $>63 \mu \mathrm{m}$ fraction. 


\section{DIESTER-HAASS}

sand, might have been intercalated and mixed into the normal hemipelagic sediments by bioturbation. A radiographic study would be useful here. Lowered sea level necessary to allow the down-slope transport of dune sand (Sarnthein and Diester-Haass, 1977) might have occurred during this period, as a consequence of arctic glaciation which began at about 3 m.y. B.P. (Berggren, 1972). In the Pacific, a glacioeustatic sea-level lowering has been determined for 3 m.y. B.P. (Schlanger and Douglas, 1974) and for 2.6 m.y. B.P. in New Zealand (Schackleton and Kennett, 1975). 